$$
\begin{aligned}
& \text { عدد أكتوبر } \\
& \text { الجزء الأول • r. r. الجود }
\end{aligned}
$$

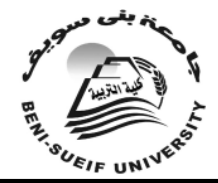

" دور الإدارة المحلية فى تجويد الأداء المؤسسى لمدارس التعليم المجتمعى بمحافظة الثرقية فى ضوء الفكر الإدارى المعاصر (دراسة ميدانية)" الباحثة/ ولاء حسين محمد جزر للحصول على درجة الماجستير قسم العلوم التربوية والنفسية - كلية التربية النوعية جامعة الزقازيق

\title{
إثراف
}

دكتورة. إيمان هانى محمود

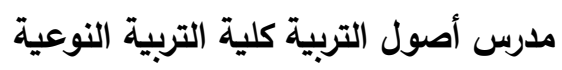
جامعة الزقازيق
الأستاذ الدكتور.عبد العظيم عبد السلام العطوانى إنقاف

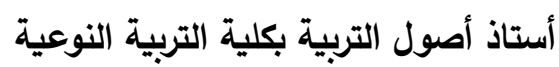

جامعة الزقازيق

المستخلص

فى الآونة الأخيرة شهد العالم طفرة تكنولوجية كبيرة أدت إلى تطورات وتغيرات كبيرة من حولنا ،ولمواكبة هذه التطورات كان لابد من تطوير نظام التعليم وعمل إصلاحات جوهرية فيه وعمل الإهل آليات للإصلاح الإدارى فيه .ونتيجه لتحول العالم إلى الإهتمام باللامركزية وتفعيل دور الإدادارة

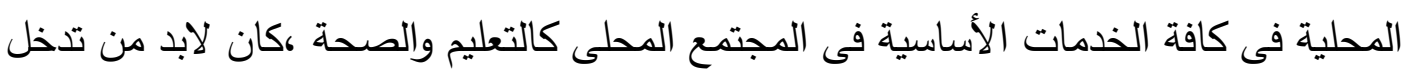
الإدارة المحلية فى تحسين جودة العملية التعليمية فى مدارس التعليم المجتمعى.وتقعيلاً للقانون

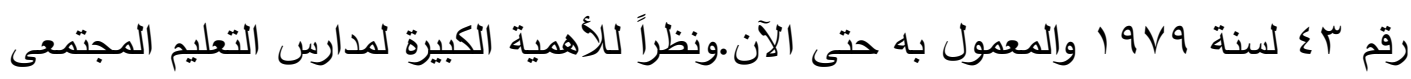

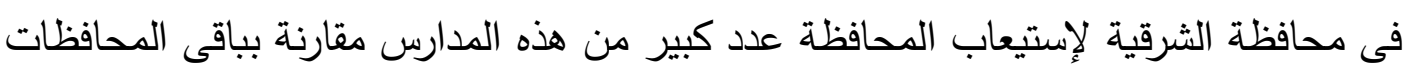
.حيث أنها توفر فرصة ثانية للأطفال الذين تسربوا من مدارسهم أو حرموا من دخولها خصوصاً. فى المناطق النائية ،بالإضافة إلى مساهمة هذه الدارس فى التصدى لظاهرة الأمية فى المجتمعات المحلية. وقد إرتكزت الدراسة على المصطلحات التالية :-الإدارة المحلية:- هى التظيم الإدارى لإقليم دولة ما والذى تلجأ بموجبه الحكومة المركزية إلى

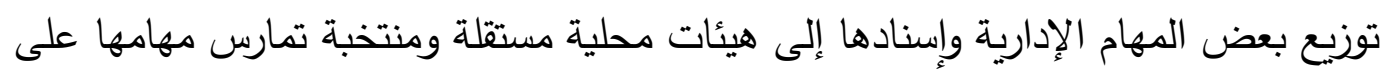
إقليم جغرافى محدد وتكون مسئولة أمام مجتمعها المحلى من قبل الحكومة المركزية . مدارس التعليم المجتمعى:- هى مدارس مكونة من فصل واحد ،تقع فى الأماكن الريفية والنائية

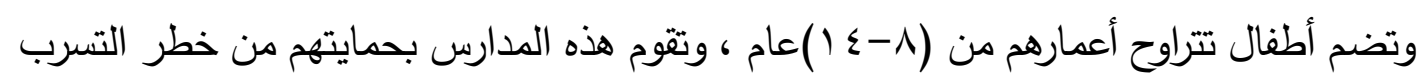
والأمية وتساعده على تحسين أوضاعهم الإقتصاية والإجتماعية من خلال تعليمه حرف بجانب المناهج الدرالسية 


$$
\begin{aligned}
& \text { عدد أكتوبر }
\end{aligned}
$$

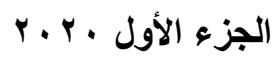

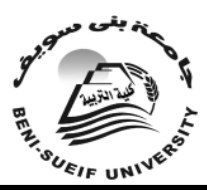

جامعة بني سويف مجائ مجلة كلية التربية

تحسين جودة العملية التعليمية:- هى تحسين نوعية الخدمة المقدمة من مدارس التعليم المجتمعى للدارسات لجذبهن للمدرسة وتحسين آدائهن لمواكبة عصر التكولوجيا والمعلومات الحيثة ومتطلبات سوق العمل. وجاءت أهم نتائج هذه الدراسة على النحو التالى:ا - كثفت النتائج عن وجود قصور شديد من الإدارة المحلية فى توفير الإحتياجات الأساسية لمدارس التعليم المجتمعى كالادوات والخامات والاجهزة اللازمة للأنشطة المدرسية . r- يوجد قصور شديد فى تحسين جودة المبانى المدرسية بمدارس التعليم المجتمعى من حيث ترميم المبانى المدرسية المتهالكة ومتابعة صيانتها وصيانة وتحديث أجهزة الحاسب الآلى ،وتخصيص قطع أراضى فى أماكن مناسبة لهذه المدارس . ب- يوجد قصور فى حل مشكلات الدارسات الإقتصادية والإجتماعية سواء من ناحية تقديم الدعم المادى أو عمل ندوات تثقيفية وتوعوية لهن أو عقد لقاءات شهرية لمحاولة حل مشاكلهن.وكذلك يوجد قصور فى توفير بيئة تعليمية جاذبة للدارسات سواء من ناحية التنسيق مع مديرية التربية والتعليم على توفير عدد مناسب من الميسرات أو من ناحية

$$
\text { توصيات الدراسة:- تدربهم على جذب الدارسات لهذه المدارس. }
$$

ا. عقد ندوات لموظفى الإدارة المحلية داخل الدواوين للتعريف بمدارس التعليم المجتمىى

$$
\text { وأهميتها فى المجتمع المحلى وتعريفهم بدورهم فى هذه المدارس. }
$$

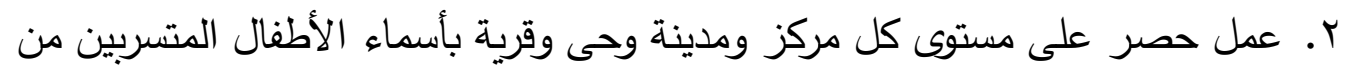
التعليم ومحاولة إلحاقهم بمدارس التعليم المجتمعى.

r. تكثيف المتابعة والإشراف على مدارس التعليم المجتمعى ومحاسبة المقصرين والمخالثين.

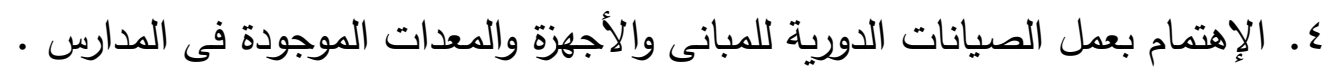
0. توفير بند مالى من صندوق خمات المحافظة لتقيم الدعم لهذه المداس وتوفير حاجاتها الأساسية. 7. متابعة تهيئة المناخ المدرسى المناسب لصقل مهارات الدارسات وتفعيل آليات التطوير الثامل والحد من المشكلات المؤثرة سلبا على آدائهم الأكاديمى ضمانا لتحسين جودة العملية التعليميةوتطبيق معليير الجودة والأعتماد بها. 


$$
\begin{aligned}
& \text { عدد أكتوبر } \\
& \text { الجزء الأول • r. r. الجئ }
\end{aligned}
$$

\section{Summary of the study in English}

The world has exposure a major technological breakthrough recently ,that led to major developments and changes around us.To keep pace with these developments, it was necessary to develop the education system ,make fundamental reforms in it, and put in place mechanisms for administrative reform in it as a result for turning the world to an attention in decentralization and activate the role of the local government in all over the basic services in local community such as education and health. All those were necessaries for interfering the local government in improving the quality of the educational process in community education schools and for applying law no.43 of 1979.the community education schools have a great importance in Sharkia governorate, because having large numbers of community education schools compared to the rest of the provinces. these schools provide second chance for children who have dropped out or prevented from school enrollment especially in remote areas. In addition to these schools decrease the illiteracy in local communities.

Terminology of study

The present study was based on the following terms:

Local government :-the administrative organization of a country's territory ,according to which the central government distributes some administrative tasks and assigns them to independent and elected local bodies that make their functions on a specific geographical region and are responsible to their local community by the central government .

Community education schools:- they are schools that consist of one class located in rural and remote places and include children between the ages of (8-14) years. these schools protect them from the danger of illiteracy and drop out and help them to improve their economic conditions by learning them handcrafts beside the school curriculum.

Improving the quality of educational process:-improving the quality of the service provided by community education schools for students to attract them to the school and improving their performance to keep pace with the age of modem technology and information and requirements of the labor market.

\section{Results}

The most important results of this study were as follows:

The results revealed that the role of the local government is insufficiency in providing the basic needs for community education schools, such as tools ,materials, and equipment needed for school activities. 


$$
\begin{aligned}
& \text { عدد أكتوبر } \\
& \text { الجزء الأول • r. r. الجوبر }
\end{aligned}
$$

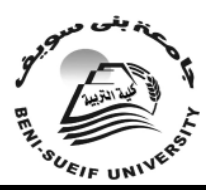

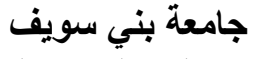 \\ مجلة كلية التربية}

-The local government's role is weak in improving the quality of the school buildings for community education school, such as restoration of dilapidated school buildings, follow up ,its maintenance and make computer's maintenance and update. Allocating plots of land in suitable places for these school .

-There is a lessening in solving the economic and social problem's students in terms of providing cash support or holding a cultural and awareness symposiums or holding monthly meeting for trying solve their problems. Also there are shortage in providing attractive learning environment for students in terms of the coordination with education directorate in providing suitable numbers of teachers and training them to attract the student for these schools. All these led to the complete separation of the local government from the community education schools.

The recommendations of the study:-

-holding symposiums for the members of local government inside their headquarter for introducing the community education schools, its importance in local society and knowing them their role in it.

-make an inventory in all over the areas by the names of children who drop out of education and try to enroll them in community education schools. -intensifying follow up and supervision of community education school, and punishing the negligents and violators.

-attention for making periodic maintenance of buildings ,devices and equipment found in schools.

-provide a financial item from the governorate services fund to provide support for these schools and providing its basic needs.

-follow up to create an appreciate school climate to sharpen the skills of students ,activate comprehensive development mechanisms, and reduce problems that negatively affect their academic performance, in order to ensure better quality of the educational process , implementation of quality standers , and accreditation.

الكلمات باللغة العربية :-الإدارة المحلية - التعليم المجتمعى - جودة العملية التعليمية

Key words :local administration-community education school-the quality 


$$
\begin{aligned}
& \text { عدد أكتوبر }
\end{aligned}
$$

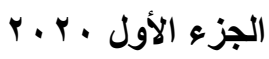

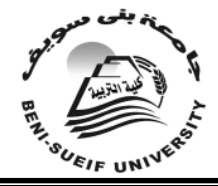

الفصل الأول:- الإطار العام للدراسة

مقدمة

فى ظل المتغيرات والمستجدات المتلاحقة التي نشهاها فى عصرنا الحالي ينبغي أن يكون

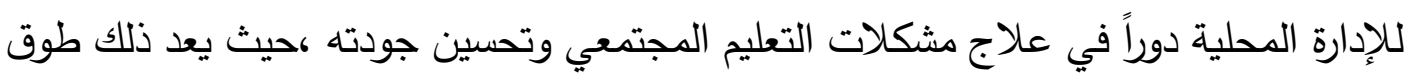

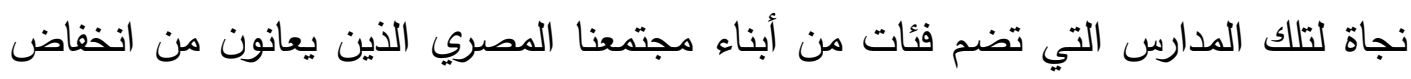

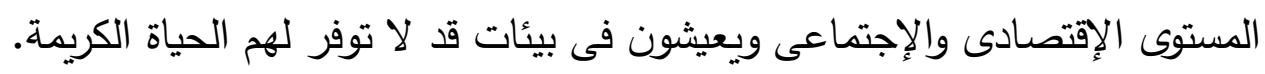

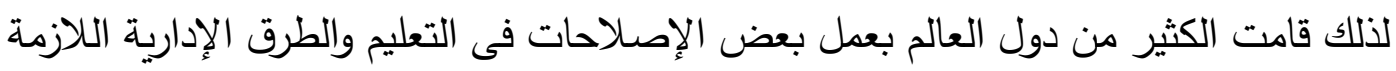

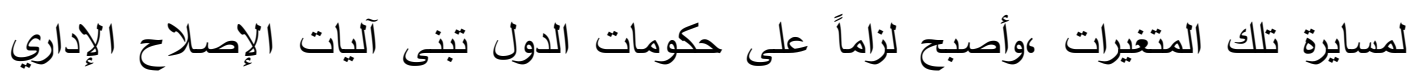

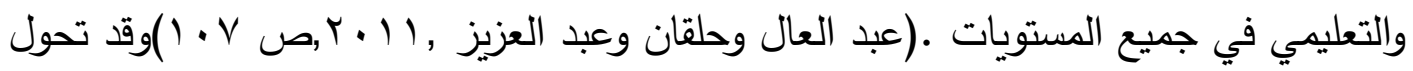

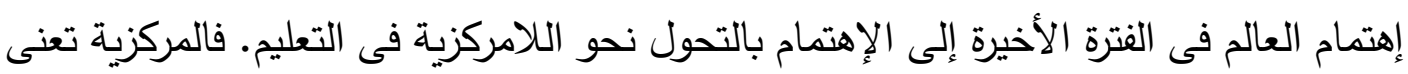

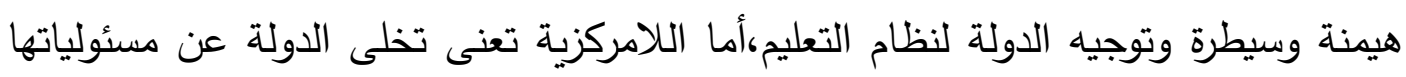
تجاه العملية التعليمية سواء بثكل كلى أو جزئى وتفويض هذه المسئوليات للمحليات

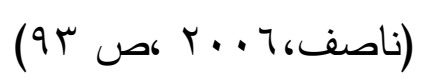

إن اللامركزية الحكومية تعطى الحكومة المحلية القوة والسلطة لإدارة التعليم ،وتستطيع الحكومة

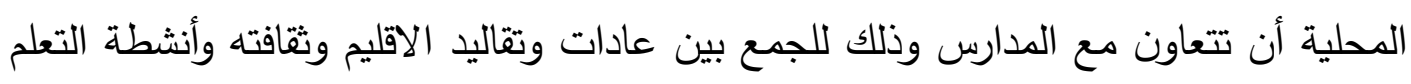

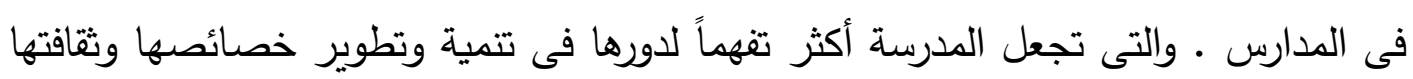

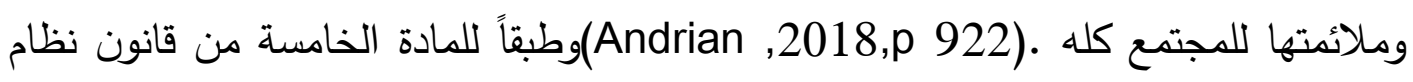

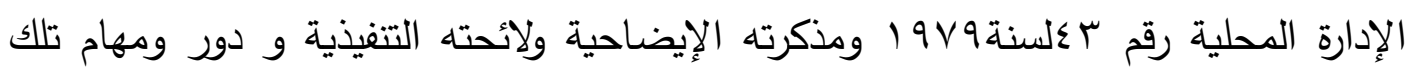

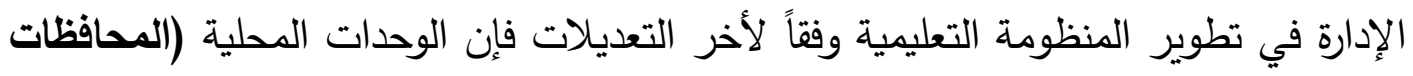

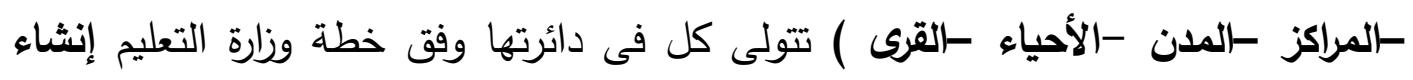
وتجهيز وإدارة المدارس عدا المدارس التجريبية ومراكز التدريب المركزية.(الإدارة العامة للشئون فئوني

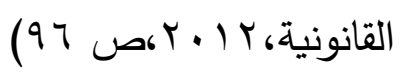
ومن المميزات التى تنفرد بها الإدارة المحلية عن غيرها قربها من المواطنين ومن حياتهم الاجتماعية ،والاقتصادية،بهدف توفير معيشة أفضل للفرد وتعمل على تكييف النظام الإداري تلني 


$$
\begin{aligned}
& \text { عدد أكتوبر }
\end{aligned}
$$

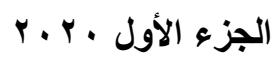

ليلائم الأفراد دون تطويعهم، واشتراك الأفراد فى إدارة الأمور ذات الأهمية المحلية،لأن الأفراد أقدر على معرفة حاجاتهم وكيفية تلبية هذه الاحتياجات،وهى مدرسة للأفراد لتربيتهم سياسياً

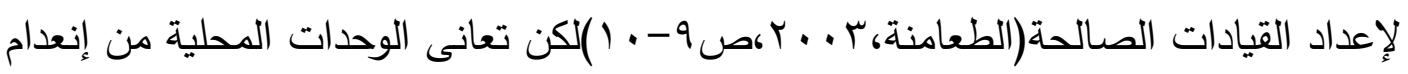
السلطات اللازمة لتحقيق أهدافها من خلال عدم فاعلية دور الوحدات المحلية والمجالس الشعبية

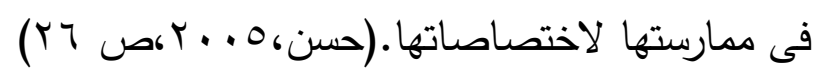

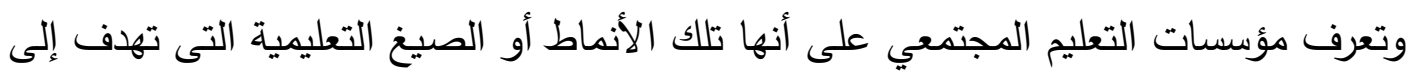
توفير فرص التعليم للأطفال فى المناطق الأقل حظاً،والمحرومة من الخدمات التعليمية فى مؤى مصر ,الذين لم تتح لهم فرصة الالتحاق بالمؤسسات التعليمية ،أو الذين التحقوا وتسربوا منها فى الثريحة العمرية (7-ء (سنة),اعتمادا على مشاركة المجتمع.وتكون صيغه :-- (مدارس المجتمع -مدارس الفصل الواحد- المدارس الصديقة للفتيات -المدارس الصغيرة -المدارس

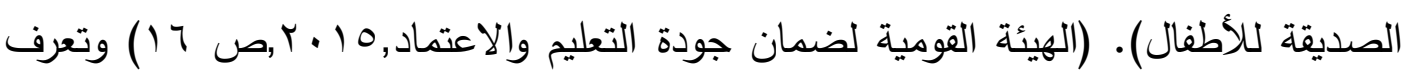
أيضاً على أنها نمط موازى للتعليم النظامى وهى فكرة متطورة تفيد فى حالات المتسربين من التعليم الإلزامى أو الذين لم ينالوا حظاً من التعليم الابتدائى أو فى حالة وجود أعداد قليلة من فن فئي الدارسات وغير متوفر مدارس إبتدائية لهن فى المجتمعات النائية التى لا يصل إليها التعليم

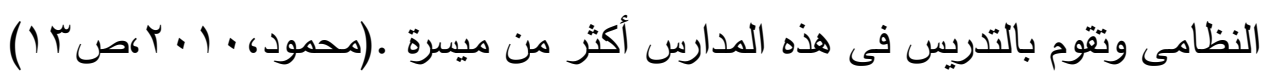
وفى الآونه الأخيرة أطلق على القرن الحادى والعشرين أنه عصر الجودة،نظراً لإرتباطه بأهداف جديدة نحو جعل النوعية والجودة الميدان الأكثر حسماً فى تحقيق أهداف المنظمات الإنسانية

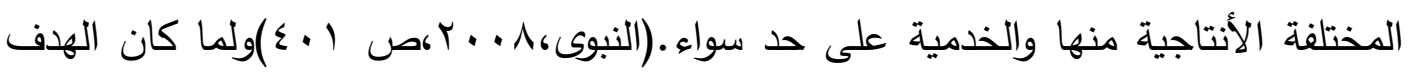

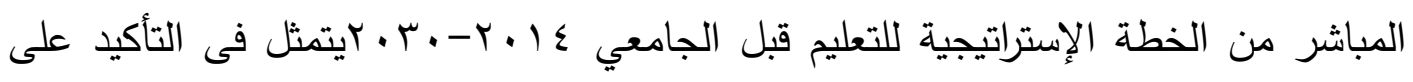
الالتزام بحق كل طفل فى فرصة متكافئة لتلقى خدمة تعليمية بمستوى من الجودة يتناسب مع الإسي المعايير العالمية، بما يسمح لله بالإسهام الفعال فى التتمية الاجتماعية والاقتصادية

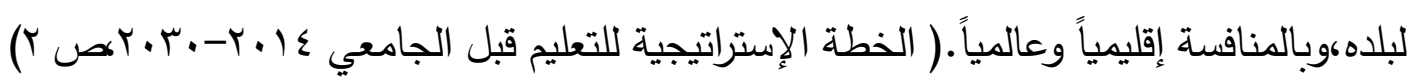
ومن هنا كان لابد من الاهتمام بتطبيق نظام الجودة وتحسين نوعية التعليم عاماً والتعليم المجتمعي خاصة،هذا وقد أوصت الهيئة القومية لضمان جودة التعليم والاعتماد بأهمية معايير 


$$
\begin{aligned}
& \text { عدد أكتوبر }
\end{aligned}
$$

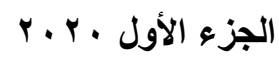

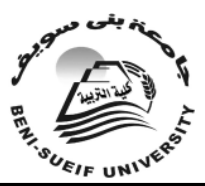

اعتماد مؤسسات التعليم المجتمعي بهدف إحداث نقلة نوعية للتعليم المجتمعي ،والعمل على تفعيل دور المؤسسات المحلية ،ومساعدة جهات المراقبة والمتابعة على أداء دورها لتحسين الجودة وحسن الأداء.وربط التعليم بالمهارات الحياتية وإدارة الحياة واحتياجات المجتمع

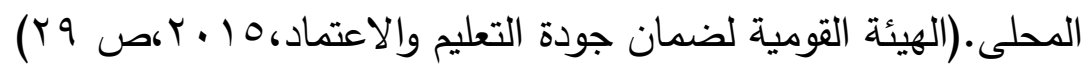
لذلك أصبح من الضرورى أن يكون للإدارة المحلية دور فعال فى حل مشكلات مدارس التعليم المجتمعى وكذلك الأهتمام بوضع حلول لتتمية وتطوير هذه المدارس لما لها من أهمية قصوى.

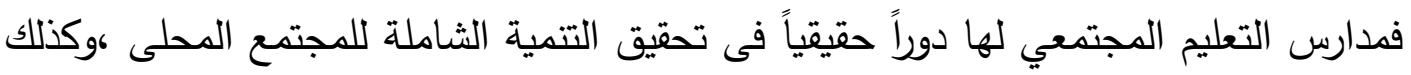
تلعب دوراً حقيقياً فى سد منابع الأمية والمشاركة فى القضاء عليها بما يحقق مبدأ التتمية

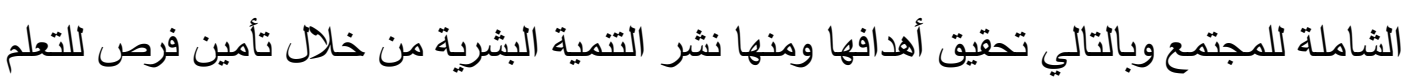

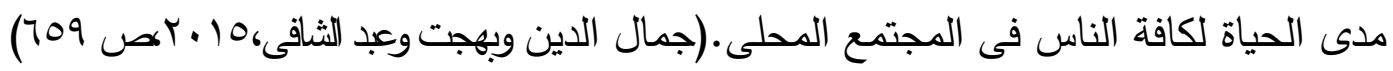
أولاًا:-مشكلة البحث وعلى الرغم من الجهود المبذولة لتحقيق النقلة النوعية فى التعليم المصري بشكل عام والتعليم المجتمعي بثكل خاص إلا أن العديد من الدراسات أثبتت أنه يوجد قصور شديد من الإدارة المحلية فى تجويد الآداء المؤسسى لمدارس التعليم المجتمعى بمحافظة الشرقية كما يلى : دراسة قرواط يونس(T ( 1 ( ) التى هدفت إلى تبنى مفهوم الإدارة المحلية لتحقيق التتمية المحلية بالتوجه المستدام الذي يعد من التوجهات الحديثة.وتوصلت الدراسة إلى أهمية التكريس الفعلي والحقيقي لسياسة اللامركزية لأنها الوسيلة الوحيدة التي تضمن استقلالية الجماعات الإقليمية ومبادرتها في مجال المشاريع التتموية المحلية توصلت أيضا إلى أن التمية المستدامة هي النشاط الاقتصادي الذي يؤدى إلى الارتقاء بالرفاهية الاجتماعية ،ودراسة محمد جمال راثد (7 ( + (Y)التى هدفت إلى التعرف على نظام الإدارة المحلية فى مصر والمشاكل التى تواجهها

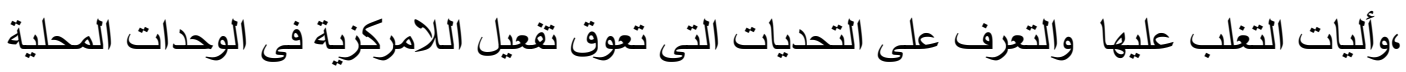

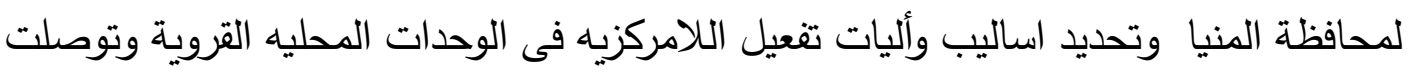
الدراسة إلى اللامركزية ضرورية للحد من البيروقراطية والروتين الحكومى و تقود إلى تحقيق

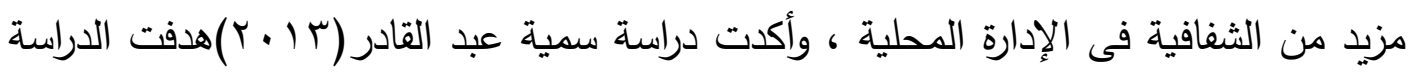




$$
\begin{aligned}
& \text { عدد أكتوبر }
\end{aligned}
$$

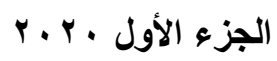

الى ضرورة الاهتمام بجودة التعليم ونظمه ونشر مبادئه والعمل على تطبيق نظام دعم ضمان الجودة والاعتماد ليعزز من شفافية المؤسسات التعليمية وينمى قدرتها على تجويد منتجاتها.وتوصلت الدراسة الى أن الجودة ليست هدفا بل هي طريق تستطيع من خلالها المؤسسات التعليمية أن تقود طلابها الى التميز والابداع والابتكار ويمكن أيضا تطبيق اعتماد معايير الجودة من خلق فرص التنافس الإيجابي بين المؤسسات العلمية في المجتمع وعلى المستوى الإقليمي والمحلى •وسوف يتضح ذلك فى الدراسات السابقة، دراسة مشيرة إبراهيم ( ) ( ا ( هدفت الدراسة إلى التعرف على أهم المشكلات الخاصة بمدارس الفصل الواحد ومحاولة

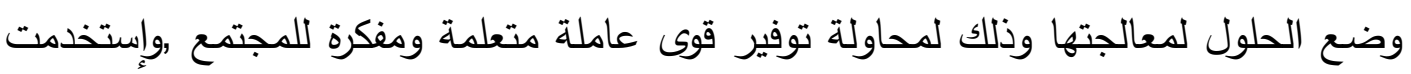
الدراسة المنهج الوصفى وإستخدمت أيضاً الزيارة الميدانية والمقابلات، وتوصلت الدراسة إلى ولى ولى أليات التغلب على مشكلات تعليم الفتيات بمدارس الفصل الواحد بالثرقيه،تزويد المبانى بوسائل تهوية ووسائل أمن صناعى وصيانة المبانى وترميمها من أجل تطبيق معايير الجودة.ودراسة

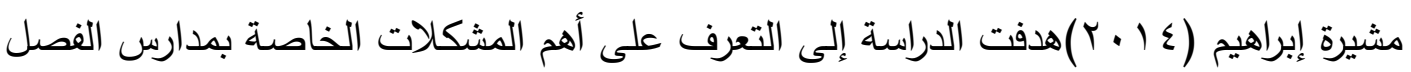
الواحد ومحاولة وضع الحلول لمعالجتها وذلك لمحاولة توفير قوى عاملة متعلمة ومفكرة للمجتمع

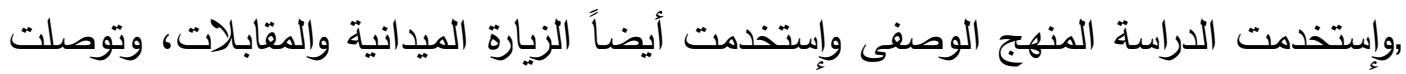
الدراسة إلى أليات التغلب على مشكلات تعليم الفتيات بمدارس الفصل الواحد بالثرقيه،تزويد المبانى بوسائل تهوية ووسائل أمن صناعى وصيانة المبانى وترميمها من أجل تطبيق معايير الجودة.وقد تبلورت مشكلة الدراسة فى عدة أسئلة منها:ا-ما مفهوم الإدارة المحلية و نشأتها ومكوناتها وأهميتها وأهدافها؟ r-ما صيغ التعليم المجتمعي ونشأته وفلسفته وأهدافه؟

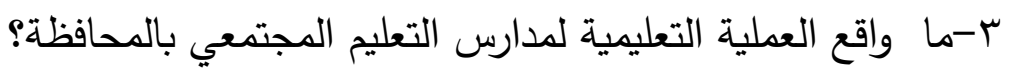
ع-ما أهم المعوقات التي تحول دون قيام الإدارة المحلية بدورها فى علاج مشكلات التعليم المجتمعي فى محافظة الشرقية؟ ه-ما أهم الإجراءات والآليات التي يجب إتخاذها في تحين جودة العطلية التعليمية بدارس التعليم المجتمعي؟ 


$$
\begin{aligned}
& \text { عدد أكتوبر }
\end{aligned}
$$

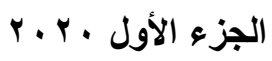

- التعرف على ماهية الإدارة المحلية من حيث فلسفتها وأهدافها والتعريف بأهميتها ودورها فى تحسين جودة العملية التعليمية بمدارس التعليم المجتمعي. -التعرف على واقع العملية التعليمية بمدراس التعليم المجتمعي في محافظه الثثرقية ومعايير الجودة بها. - الكثف عن المعوقات التي تحول دون قيام الإدارة المحلية ببورها في مدرل التعليم المجتمعي بمحافظه الثرقية .

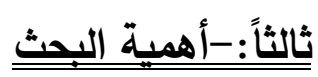
- إلقاء الضوء على دور الإدارة المحلية فى تحسين جودة مدارس التعليم المجتمعي :نظرا لأهمية التعليم المجتمي ونظراً للإهمال الواضح من الإدارة المحلية للقيام بدورها تجاه المؤسسات التعليمية عاماً و التعليم المجتمعي خاصاً والذي لله أهمية كبيرة تتعكس على المجتمع كله. وتتتاول الدراسة أهم المعوقات التي تحول دون قيام الإدارة المحلية بدورها فى مؤسسات التعليم المجتمعي وهذا الجانب تتفرد به الدراسة الحالية نظرا لقلة الأبحاث فى هذا المجال على حد علم الباحثة . رابعاً:-منهج البحثي وهذان تعتمد الدراسة على المنهج الوصفي التحليلى والذي يقوم على دراسة الظاهرةكما هى فى الوقت الحاضر. خامساً:-أدوات البحث تم الاستعانة بالدراسة الميدانية بما يتضمن من أدوات مثل إستمارة مقابلة كوسيلة أساسية في جمع البيانات اللازمة وكذلك الدراسات المسحية واستفسارات تقصى الحقائق . سادساً:-- عينة البحث اشتملت عينة الدراسة على (9 () من رؤساء الوحدات المحلية (المراكز - المدن -الأحياء) كممثلين للإدارة المحلية بمحافظة الشرقية . سابعاً:-- مصطلحات الاراسة (local government-local administration) الإدارة المحلية مصطية تعرف أيضاً على أنها الجزء من الدولة الذى يختص بالمسائل التى تهم سكان منطقة معينة

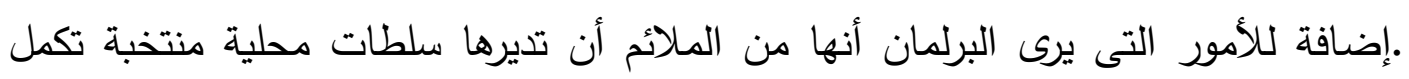

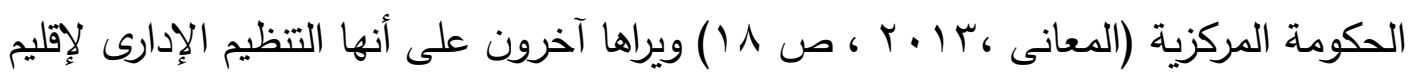




$$
\begin{aligned}
& \text { عدد أكتوبر } \\
& \text { الجزء الأول • r. r. الجوبر }
\end{aligned}
$$

دولة ما والذى تلجأ بموجبه الحكومة المركزية إلى توزيع بعض المهام الإدارية وإسنادها إلى هيئات محلية مستقلة ومنتخبة تمارس مهامها على إقليم جغرافى محدد وتكون مسئولة أمام

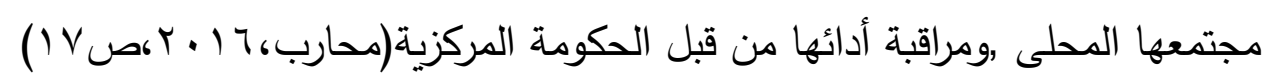
-مدارس التعليم المجتمعى:-) عرف محمد عوض البربرى مؤسسات التعليم المجتمعى على أنها "صيغة عصرية لمؤسسات التعليم قبل الجامعى ، تقوم بتوفير فرص التعليم للجميع و التعليم المستمر للأطفال المحرومين

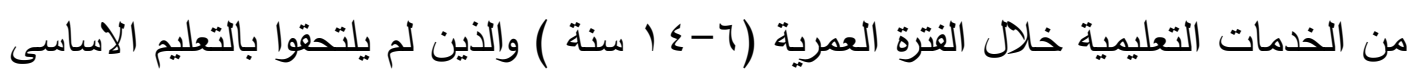
أو تسربوا منه و الاحتفاظ بهم حتى إكمال هذه المرحلة التعليمية، خاصة فى المناطق الريفية

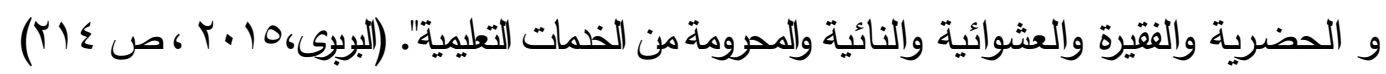
التعريف الإجرائى لمدارس التعليم المجتمعى:-هى مدرسة مكونه من فصل واحد تضم دارسين حردن أو تسربن من التعليم وتتراوح أعمارهن بين (1-ـ ( ) عام وتكون موجهه للفئات المهمشة

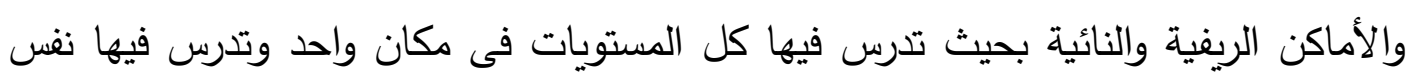
مقررات المدارس الإبتدائية بالإضافة إلى التكوين المهنى والمشروعات الإنتاجية والصيفية.

\section{(الجيودة (QUALITY)}

فالجودة في التعليم تعنى بأنها جملة المواصفات أو المعايير أو الخصائص في العمليات الإدارية التي تؤدى إلى تقديم أداء متميز يساعد في تحسين العملية التعليمية إذ أن هذه العمليات تتمثل في التخطيط والتنظيم والتوجيه والرقابة والتقويم يقوم بها القائمين على الإدارة والأفراد المسئولين

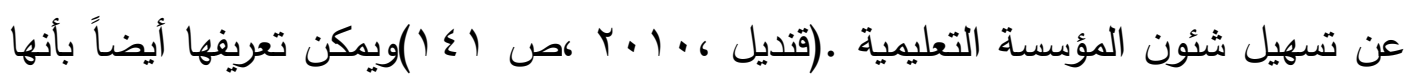
هي مجمل السمات والخصائص التي تتعلق بالخدمة التعليمية وهى التي تفي باحتياجات الطلاب كما أن تحقيق جودة التعليم يتطلب توجيه كل الموارد البشرية والسياسات والنظم والمناهج

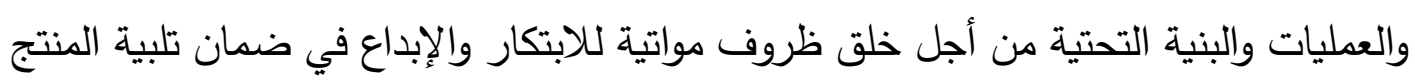

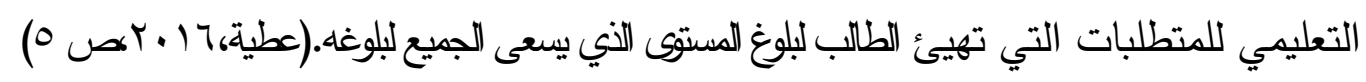




$$
\begin{aligned}
& \text { عدد أكتوبر }
\end{aligned}
$$

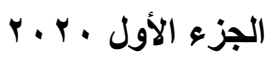

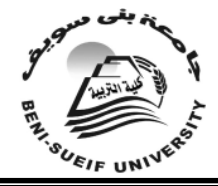

\section{ويقصد بجودة العملية التعليمية إجرائياً في هذه الاراسة}

أن يتلقى الدارسات الخدمة التعليمية فى بيئة تعليمية صالحة للتعلم الفعال بحيث يتوافر لهن المبانى المدرسية التى تتاسب العملية التعليمية وتخضع للإشراف والمتابعة والصيانه الدورية ويتلقون المناهج الدراسية والأنشطة المدرسية من قبل معلمات مدربات يستخدمن فيها كافة الأجهزة والأدوات الحديثة التى تخضع للصيانة والتحديث بشكل دورى . ثامناً:-الاراسات السابقة والتِ

دراسة أحمد محمد المومنى وغسان عيسى العمرى (10 ب ب) هدفت الدراسة إلى التعرف على

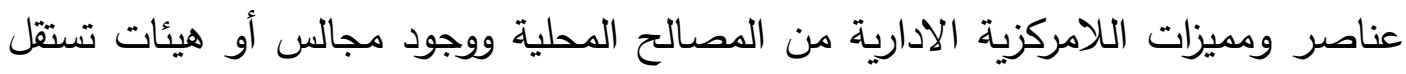
بإدارة هذه المصالح ووجود رقابة إدارية من جانب السلطة المركزية والتعرف على تطور اللامركزية الادارية فى عهد النبي (صلى الله عليه وسلم)وعهد الخلفاء الراشدين حتى العهد العباسي.وتوصلت الدراسة الى ان الدولة الاسلامية منذ عهد النبي (صلى الله عليه وسلم) وحتى العصر الثاني من الدولة العباسية قد طبقوا عناصر اللامركزية الادارية .

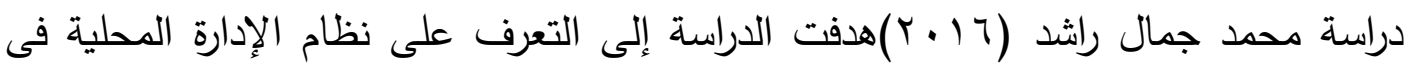
مصر والمشاكل التى تواجها ،وأليات التغلب عليها والتعرف على التحديات التى تعوق تفعيل اللامركزية فى الوحدات المحلية لمحافظة المنيا وتحديد اساليب وأليات تفعيل اللامركزيه فى الوحدات المحليه القروية وتوصلت الدراسة إلى اللامركزية ضرورية للحد من البيروقراطية والروتين الحكومى و تقود إلى تحقيق مزيد من الثفافية فى الإدارة المحلية.

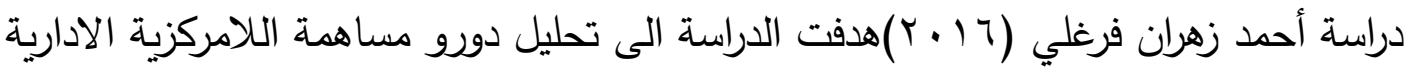
في تحقيق التتمية المحلية من خلال قيامها بالحد من الفساد الموجود في وحدات الادارة المحلية المصرية ،وتوصلت الدراسة الى تفعيل النهوض المتعلقة باللامركزية في القوانين الحالية وتحقيق التوازن في العلاقات بين المجالس الثعبية المحلية والمجالس التنفيذية وان يكون التمثيل فى المجالس الشعبية المحلية على اساس عدد السكان وكذلك اعادة النظر في تعد المستويات المحلية.

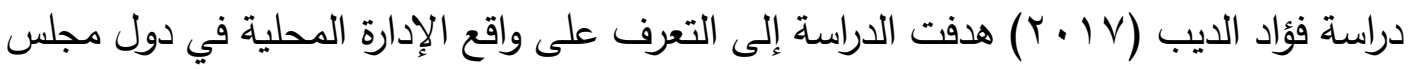
التعاون الخلجي (قطر -الامارات العربية المتحدة). توصلت الدراسة الى ان البلديات في كلتا 


$$
\begin{aligned}
& \text { عدد أكتوبر }
\end{aligned}
$$

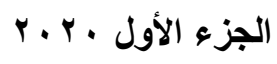

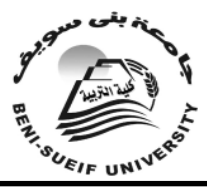

\section{جامعة بني سويف} مجلة كلية التربية

الدولتين تعانى من ضعف الاختصاصات وقلة الموارد المالية الذاتية الامر الذى يقتضى تدخل تشريعي لتفعيل الاختصاصات البلية وتحيد وزيادة الموارد المالية لتجح البلليات فى الاطلاع بورها في التتمية. r-جودة التعليم

دراسة عبد الله عودة(^ ، . ب)هدفت الدراسة إلى التعرف على مدى تحقيق مشروع تحسين جودة

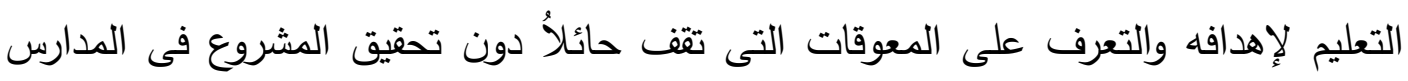
والمقترحات التى يمكن أن تساهم فى إزالة المعوقات.وتوصلت الدراسة إلى ضرورة لئى زيادة فاعلية (الشراكة مع الأسرة -خدمة المجتمع المحلى-تعبئة موارد المجتمع المحلى -تقوية الإتصال والعلاقات العامه-المتابعة والتقييم المستمر )فى تحسين جودة التعليم فى مدارس التعليم الأساسى. دراسة التويجرى (1) (1) (1) هدفت الدراسة الى تطور الاهتمام بالجودة في مدارس التعليم بالإضافة إلى التعرف على المشاركة المتميزة والمميزات التي يمكن تنفيذها في نظام مدارس المملكة العربية السعودية .وتوصلت الدراسة الى كيفية الوصول الى الجودة وكيف يمكن ضمان الجودة للمستفيدين وتسليط الضوء على التعاون الذى من المكن ان يحدث لمساعدة مختلف المستفيدين للوصول الى اكبر درجة ممكنة لتحسين جودة العملية التعليمية .

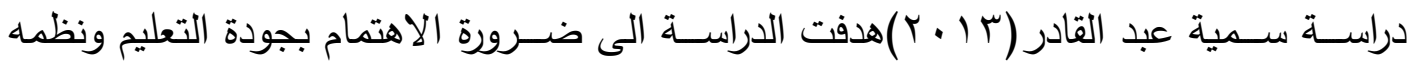
ونشـــر مبادئه والعمل على تطبيق نظام دعم ضـــمان الجودة والاعتماد ليعزز من شـــفافية

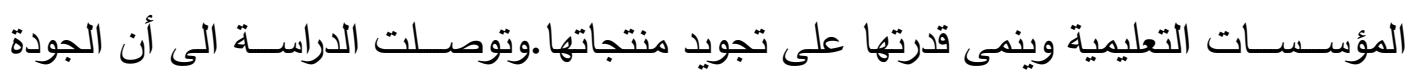
ليست هدفا بل هي طريق تستطيع من خلالها المؤسسات التعليمية أن تقود طلابها الى التميز والابداع والابتكار ويمكن أيضـا تطبيق اعتماد معايير الجودة من خلق فرص التنافس الإيجابي بين المؤسسات العلمية في المجتمع وعلى المستوى الإقليمي والمحلى •

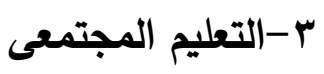
دراسـة هالة الجلاد(^ . . ب)هدفت الدراسـة إلى وضـع تصـور مقترح لمشـاركة المجتمع المحلى

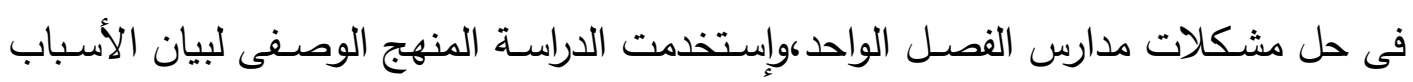

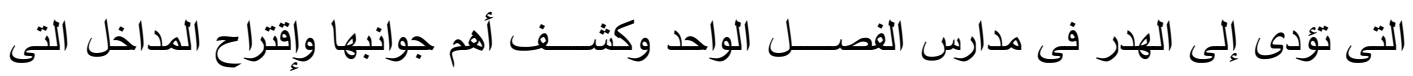
يمكن من خلالها الحد من السلبيات من خلال مشاركة المجتمع المحلى. 


$$
\begin{aligned}
& \text { عدد أكتوبر }
\end{aligned}
$$

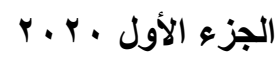

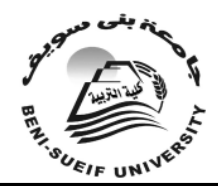

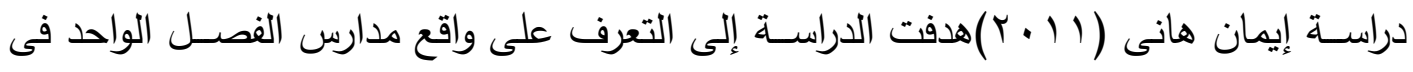
مصـر والمشكلات التى تواجهها وتعوقها عن القيام بدورها فى ضــوء الإحتياجات المجتمعية

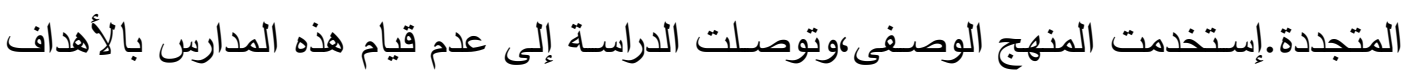
التى أنثأت من أجلها وهى توصيل الخمات التعليمية للكنور والنجوع والتزب التىى لا يوجد بها أى خلىات تعليمياء. فاطمة محمد بهجت (1) ( ب)هدفت الدراســــة إلى التعرف على واقع تعليم الفتيات فى مطلع

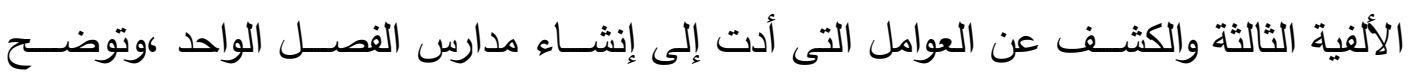

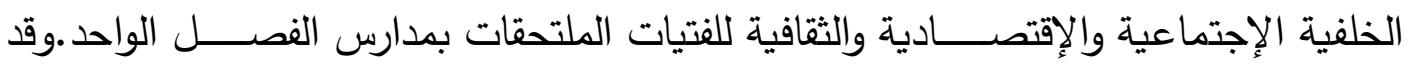
إســتخدمت الدراســة المنهج الوصــفى التحليلي بخطواته التى تســاعد على وصــف الظـاهرة

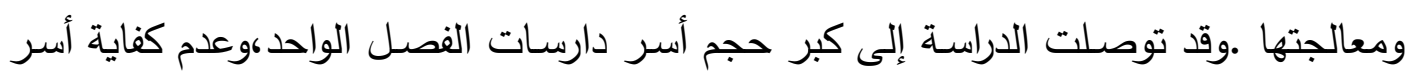

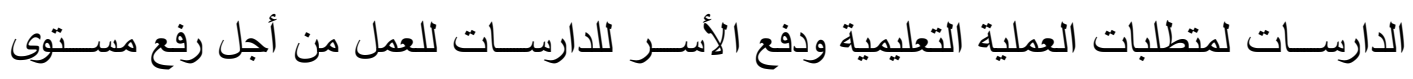
المعيشة والمساعدة فى تربية أخواتهن. دراسة مشيرة إبراهيم (ع ( ـ ؟)هدفت الدراسة إلى التعرف على أهم المشكلات الخاصة بمدارس الفصل الواحد ومحاولة وضع الحلول لمعالجتها وذلك لمحاولة توفير قوى عاملة متعلمة ومفكرة

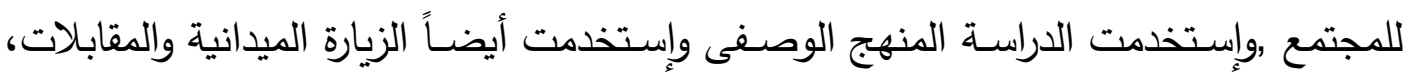

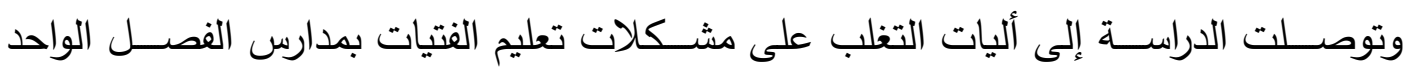
بالثرقيهتزويد المبانى بوسائل تهوية ووسائل أمن صناعى وصيانة المبانى وترميمها من أجل تطيق معايير الجودة.

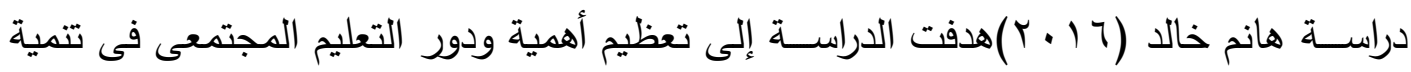
الوعى البيئى للدارسات خاصاً فى المناطق الفقيرة والمهمشة والنائية ،تم إستخدام المقابلة شبه المفتوحه كأداة من أدوات الدراســة وتوصـلت الدراســة إلى التركيز على جوانب الوعى البيئى الثلاث (المعرفى والوجدانى والسـلوكى) وتفعيل دور العملية التعليمية فى نثـــر الوعى البيئى وتفعيل دور الأنشطة التربوية فى تتمية الوعى البيئى للدارسات. الفصل الثانى الإدارة المحلية

مما لا شك فيه أن للإدارة المحلية أهمية كبيرة و دور مهم فى تحقيق التنمية الشاملة للدول

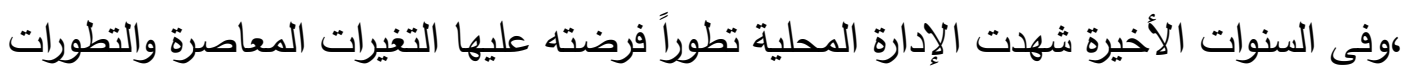




$$
\begin{aligned}
& \text { عدد أكتوبر }
\end{aligned}
$$

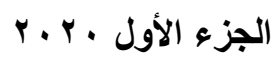

السريعة المتلاحقة، ولذلك فان الاهتمام بنظام الإدارة المحلية وتطويرها فى هذه الأيام ضرورة لتحقيق الديمقراطية في أي دولة عصرية ـ فبالإدارة المحلية تتحقق التتمية الاقتصادية والسياسية والاجتماعية للمجتمع كله. ومع تصاعد الاهتمام بالمواطن المصري فى العقود الأخيرة فى سياق الاستثمار البشرى والتمية المستدامة فقد أصبح نظام الإدارة المحلية من أهم مقومات الحياة السياسية والاقتصادية والاجتماعية السليمة.

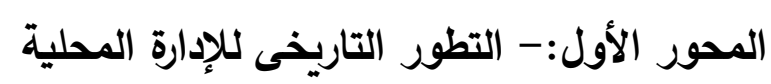

عندما جاء الملك مينا ليوحد مصر كان يختار الحاكم على كل إقليم بنفسه ،وكان من حق الحاكم الإشراف على القضاء وجباية الضرائب بجانب الأعمال الكتابية وكان هناك مجالس للأعيان فى الوجه البحرى بمثابة حلقة وصل بين الملك وسكان الأقليم ،وفى الصعيد كان تدخل الحكومة المركزية أشد وأقوى، وننقسم كل إقليم إلى مقاطعات ولكل مقاطعة شخصيتها المعنوية

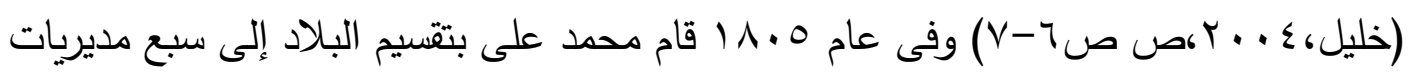
يتبع كل مديرية عدد من المراكز وتنقسم إلى عدة أقسام تضم مجموعة من القرى ،وكانت الحكومة المركزيـة على رأس هذا النظام الإداري، وقد أنشأ محمد على المجالس والدواوين لتعاونه

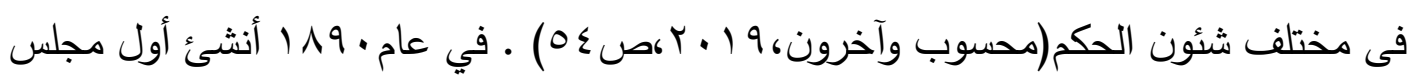
بلدي فى الإسكندرية وبذلك تكون مصر من أوائل الدول العربية التي أَنشئ فيها نظام الإدارة المحلية ،وفى عام سو^1 أصدر مجلس الوزراء قرار بإنشاء مجالس محلية فى بعض المدن

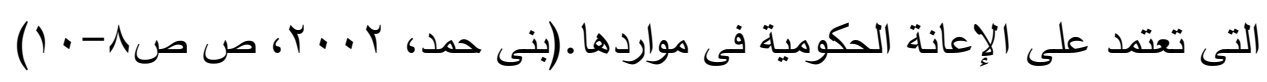
ومن خلال صدور دستور بr 9 1, كان أول إعتراف دستورى للنظام المحلى خاصة فى المادتان ץ او سبا وما نصت عليه من تشكيل جميع مجالس المديريات والبلديات بالانتخاب، إلا أن تلك الشخصية ظلت معطلة فترة من الزمان لعدم وجود مجالس فى الكثير من المدن

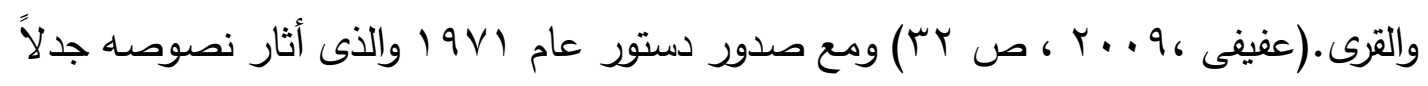
كبيراً حيث نص على إنشاء المجالس الثعبية المحلية ويكون جميع أعضائها منتخبين انتخاباً مباشراً ،ولم ينص على مشاركة التنفيذيين عضوية هذه المجالس الثعبية كما أنه لم يشر إلى إلى 


$$
\begin{aligned}
& \text { عدد أكتوبر }
\end{aligned}
$$

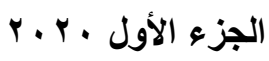

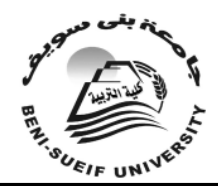

وجود مجلس للتنفيذيين بالإضافة أنه لم يشر إلى كيفية تعيين أو إختيار رئيس الوحدة المحلية

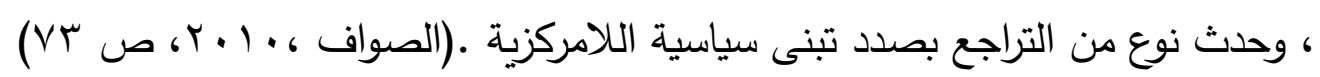

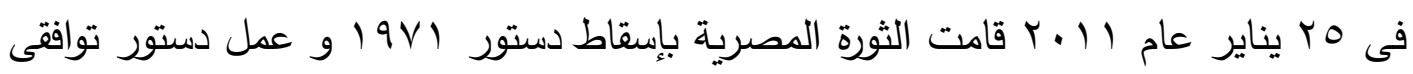

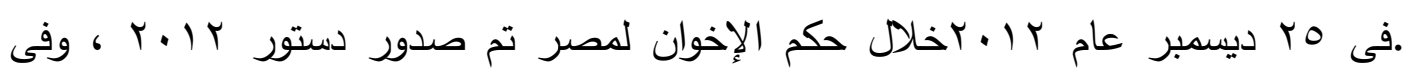

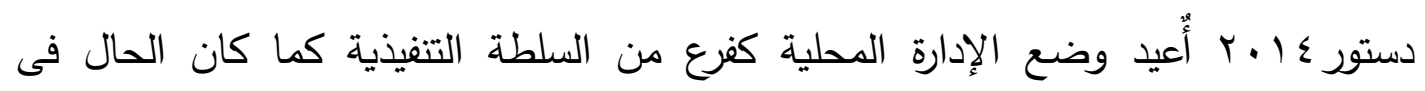
دستور (9V1 (لذلك فإنه تضمن مجموعة غير مسبوقة من النصوص الخاصة بالإدارة المحلية بهدف دعمها والارتقاء بها مثل دعم اللامركزية الادارية والمالية والاقتصادية والاستقلال المالى مئى

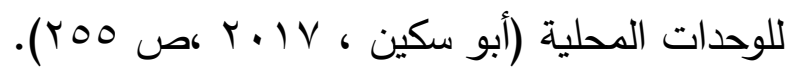

$$
\begin{aligned}
& \text { المحور الثانى:- مفهوم الإدارة المحلية }
\end{aligned}
$$

ومن الخلفية التاريخية والقانونية للإدارة المحلية يتضح مغزاها الخاص بين كل أصحاب المصالح بسبب الحدود المحلية التى تساعد على التنسيق والتعاون والثراكة بينهم لبناء عاصمة إجتماعية(372, 2005, Kearns).وهى تعتبر التظيم الرسمى المنشأ بالقانون و لله

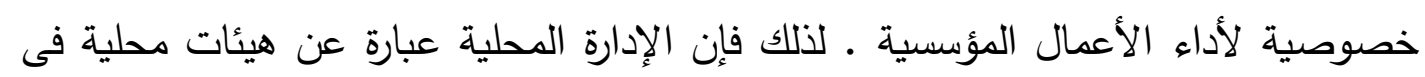
أقاليم معينة متوفرة بقوة ذات مهام ومسئوليات أكثر أهمية وتؤثر على عملية صنع القرار وتتحكم فيه دون تدخل من الجهات العليا الحكومية ( p.20, 2012, Alo).وتعرف أيضاً على أنها التتظيم الإدارى لإقليم دولة ما والذى تلجأ بموجبه الحكومة المركزية إلى توزيع بعض المهام

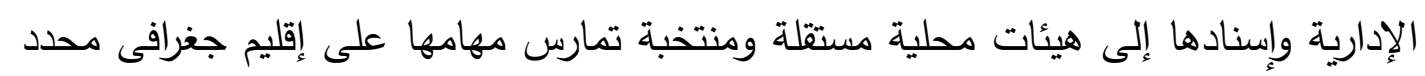

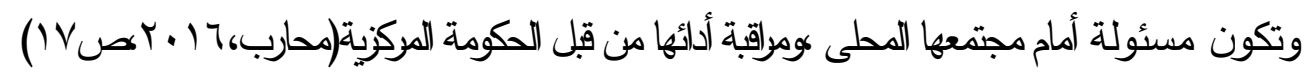
لكن هذه التعريفات تفتقر إلى الهدف الأساسى للإدارة المحلية حيث إهتمت التعريفات فقط بتقسيم الأقاليم إلى وحدات وأهملت شرط تحقيق مصلحة السكان المحليين وهو تحقيق رضى المواطن والعمل على توفير الحياة الكريمة لله بشتى الطرق ـ لذلك يمكن تعريف الإدارة المحلية على الذى أنها [ أسلوب من أساليب الإدارة يقسم إقليم الدولة إلى وحدات محلية تتمتع بالثخصية الاعتبارية ويمثلها مجالس منتخبة يكون هدفها وشغلها الشاغل هو تحقيق التنمية والرفاهية للمجتمع المحلى بلى باليه وتحقيق رضى المواطن المحلى مهما كانت الظروف وذلك تحت رقابة الحكومة المركزية .ويمكن هون 


$$
\begin{aligned}
& \text { عدد أكتوبر }
\end{aligned}
$$

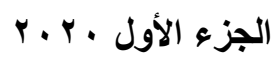

تعريف اللامركزية أيضاً على أنها نقل مسئولية التخطيط والإدارة وتنمية الموارد وتخصيصها من الحكومة المركزية إلى كلاً من [وحدات تابعة للحكومة-وحدات ميدانية تابعة للوزارات والهيئات الحكومية-هيئات عامة شبه تلقائية-منظمات تابعة للقطاع الخاص-إقليم واسع (Harasha,2005,pp1-12)·النطاق] ويمكن الإثارة إلى أنواع اللامركزية كما يلى:اللامركزية السياسية:- عبارة عن توزيع الوظائف الحكومية بين الحكومة المحلية و المراكز

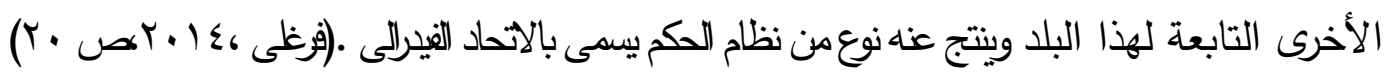
اللامركزية الإدارية:- وهى تهدف إلى نقل المسئولية الإدارية [التخطيط-التمويل-الإدارة]من لإني

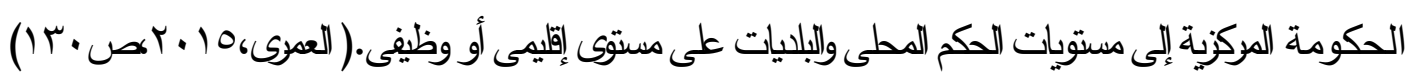
اللامركزية المالية:- نقل مسئوليات الإنفاق والتمويل من الحكومة المركزية إلى الوحدات المحلية بهدف الأستغلال الكفـ المواردولتحقيق اللامركنية يجب أن يكون لليها سلطة صنع قرارات الإيرادات والإثفاق. اللامركزية الأقتصادية أو لامركزية السوق:- ويقصد بها نقل مسئولية الإمداد بالخدمات العامة

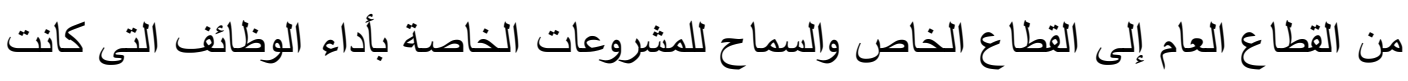

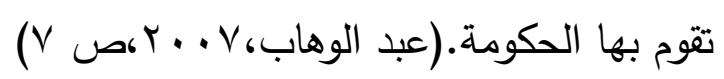

والحكم المحلى مرتبط بالادارة المحلية لكونه يعتبر مفهوماً ملازماً لمصطلح اللامركزية التى يتم بموجبها تخويل الادارة المركزية صلاحيتها و بعضاً من اختصاصاتها للأجهزة الادارية المحلية

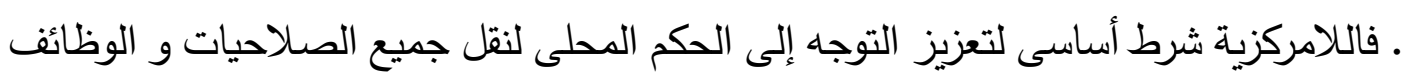
إلى المستوى المحلى بغية تقريب الإدارة من المواطن و لسهولة التعرف على المشاكل الموجودة

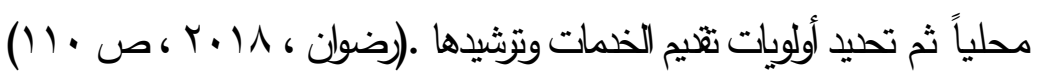

$$
\begin{aligned}
& \text { المحور الثالث:- أهداف الإدارة المحلية }
\end{aligned}
$$

-أهداف سياسية تتمثل فى إتاحة فرصة التربية السياسية للمواطنين من خلال تقريب الإدارة

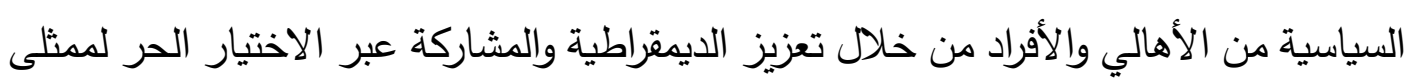

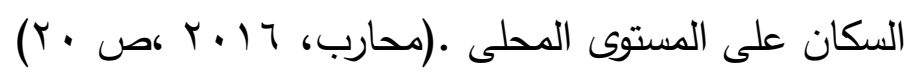




$$
\begin{aligned}
& \text { عدد أكتوبر }
\end{aligned}
$$

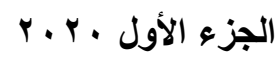

-أهداف اجتماعية تتمثل فى دعم العلاقة بين الحكومة والمواطن وترسيخ رغبته فى المشاركة

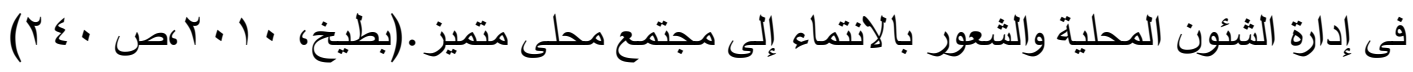

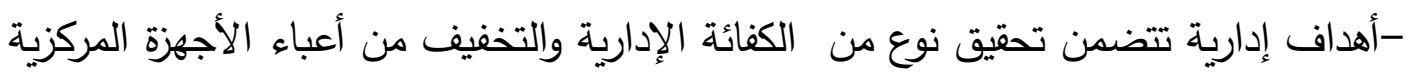
والتغلب على مشكلات البيروقراطية وخلق روح التنافسية بين وحدات الإدارة المحلية.

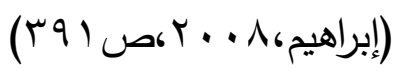

-أهداف إقتصادية من خلال قيام الوحدات المحلية بإعداد خطط التتمية والاستفادة من الامكانيات الاقتصادية المحلية ،وتوظيفها للمشروعات الانتاجية و الخدمية وذلك لخلق فرص عمل للمواطنين المحليين ،وتثجيع تجميع رؤؤس الأموال المحلية وتوجيهها نحو المشروعات .

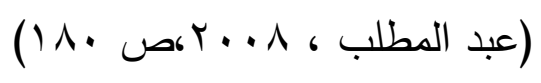

المحور الرابع :- واقع الإدارة المحلية فى مصر ومشكلاتها إن الإدارة المحلية هى نظام حكم يهتم بالأمور المحلية ويسهم فى حل العديد من المشاكل ويبعد عن هرمية السلطة ويتمثل واقعه فيما يلى:أولاً :- إختيار القيادات التنفيذية المحلية

يتم إختيار القيادات التنفيذية المحلية (المحافظ-رئيس المدينة سئيس المركز ـرئيس الحىـ السكرتير العام-السكرتير العام المساعد) بالتعيين ،ويتم شغل معظم هذه الوظائف لرجال القوات

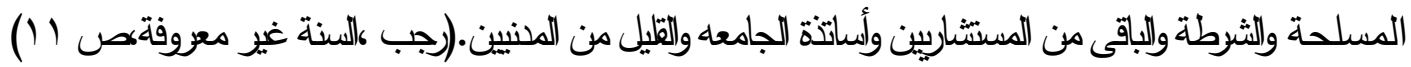
ثانياً العلاقة بين الإدارة المحلية والحكومة المركزية مازالت العلاقة بين الإدارة المحلية والحكومة المركزية علاقة تتتصر فيها الحكومة المركزية ،وبالرغم من أن القانون يعطى الحق للمحافظ بالسلطة التأديبية للعاملين بمديريات الخدمات إلا

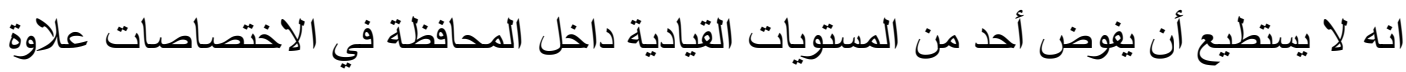
على ذلك عدم قدرته على نقل اى مبلغ من بند إلى بند في موازنة المحافظة قبل موافقة وزارة

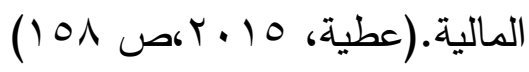




$$
\begin{aligned}
& \text { عدد أكتوبر } \\
& \text { الجزء الأول • r. r. الجوير }
\end{aligned}
$$

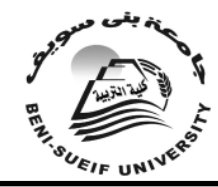

\section{جامعة بني سويف كجة التئة} مجلة كلية التربية

ثالثاً الأداء المحلى الحالي

لقد توقف دور المجالس الثعبية المحلية نهائياً بعد ثورة هب يناير ،وأصبحت القيادات المحلية

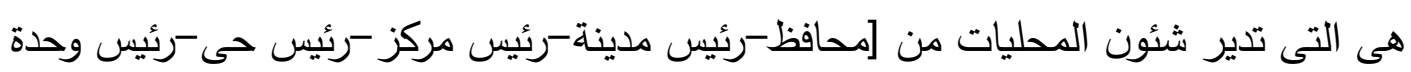

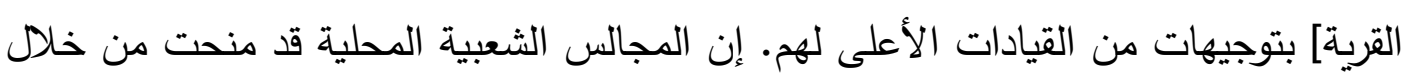

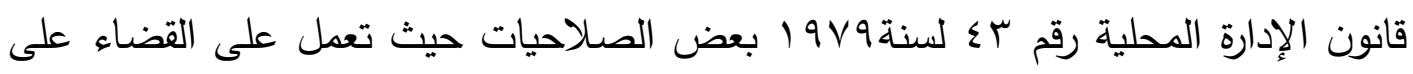

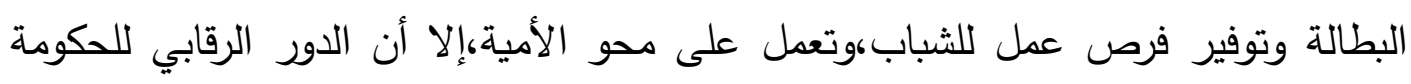
المركزية أفقدها الكثير من الفعاليات وانحصر دورها فى الإشراف والاقتراحات وإصدار

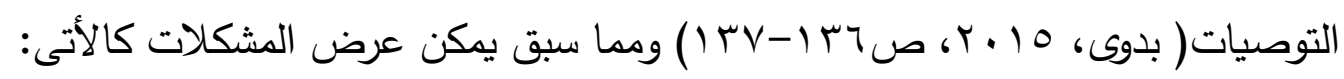

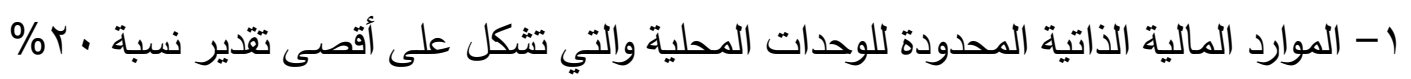
من حجم الموازنة المحلية , بينما تحصل الوحدات المحلية على النسبة الباقية كإعانة من

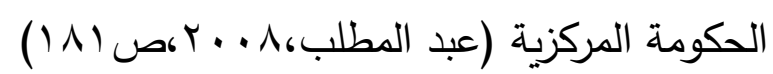
r- استجابة القيادات المحلية لأولويات التنمية واحتياجات المواطنين المحليين تكون ضعيفة. r- تبعية الوحدات المحلية للحكومة المركزية في زيادة مستمرة . ع -عدم قدرة المجالس المحلية على إقرار خطط تفصيلية للإنفاق على أساس سنوي. .(عبد الوهاب

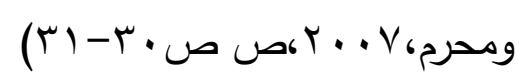

0-عدم تطبيق اللامركزية الحقيقية , فحتى الآن لم يتم تزويد الوحدات المحلية بالسلطات التي تسمح لهم بتطبيق اللامركزية الحقيقية . ج-بعض الخلل في العلاقة بين المجالس الشعبية المحلية والمجالس التنفيذية فى قواعد تحديد المسؤولية والعلاقات بين مستويات الحكم وخضوع الحكومات للمساءلة.

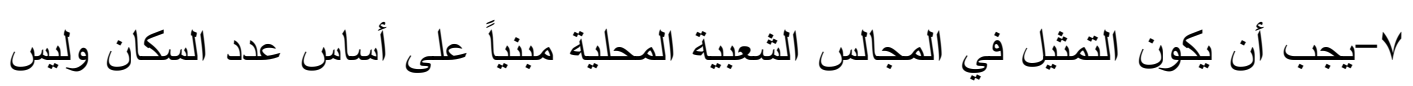

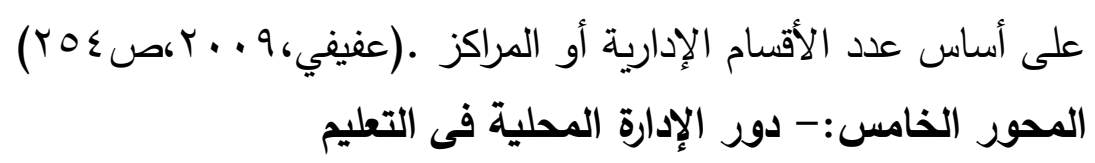
شهد العالم فى السنوات الأخيرة طفرة نوعية فى تحسين الخدمات المحلية والتوجه نحو منح مزيداً من الإستقلالية للإدارة المحلية،وتبنى غالبية الدول الكبرى طريق التقدم المتنامى فى العلم 


$$
\begin{aligned}
& \text { عدد أكتوبر }
\end{aligned}
$$

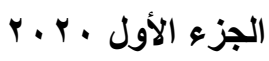

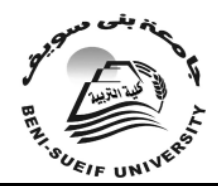

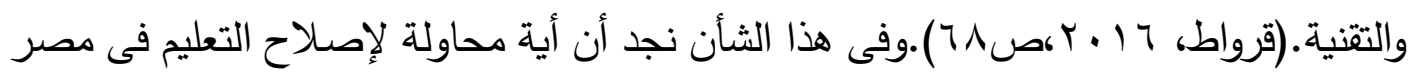
لابد أن تبدأ من المجتمع المحلى وذلك تحقيقاً للمادة الخامسة من قانون الإدارة المحلية رقم الته

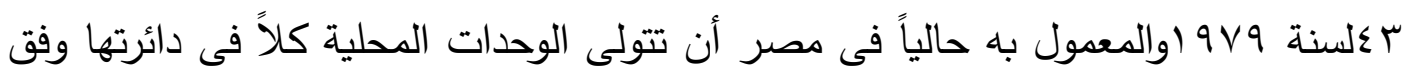
خطة وزارة التعليم إنشاء وتجهيز وإدارة المدارس عدا المدارس التجريبية و مراكز التدريب

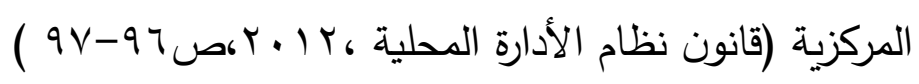
الفصل الثالث:- مدارس التعليم المجتمعي المحورالأول :- نشأة وتظور مدارس التعليم المجتمعي

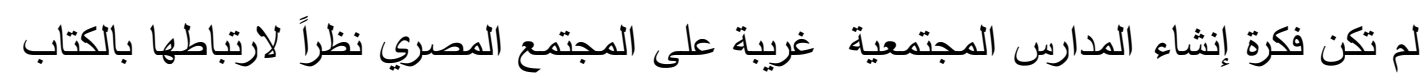
المصري الذي كان يهدف إلى حفظ المتعلمين لآيات القرآن الكريم بالإضافة إلى تعليمهم مبادئ

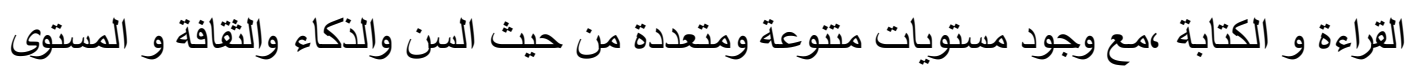

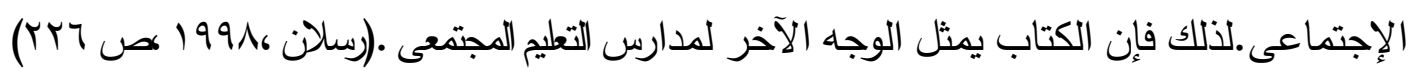
ولمواجهة احتياجات الفئات المحرومة من التعليم في عام •11 ام ،تم إنثاء مكاتب عامة بكل قرية ونجع والتي تحولت بعد ذلك لمدارس للتعليم الإلزامي لتوفير الخدمات الأساسية من التعليم لهذه القرى وتحقيق الاستيعاب الكامل في التعليم كوسيلة لمكافحة منابع الأمية .(عبد الحميد

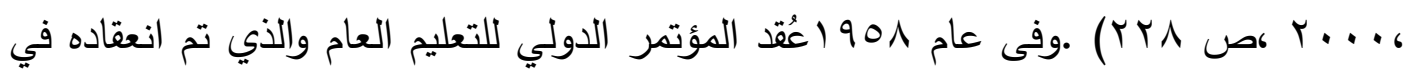
جنيف بشأن تنظيم المدارس الابتدائية ذات المعلم الواحد ،وتم التأكيد عليها في دورة انعقاده في عام الو 19 بتوصية رقم or بشأن تيسير التعليم الثعبي الالزامى في المناطق الريفية .(الهيئة

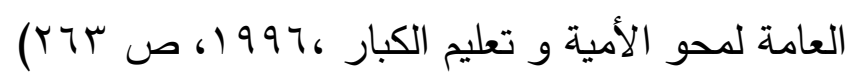

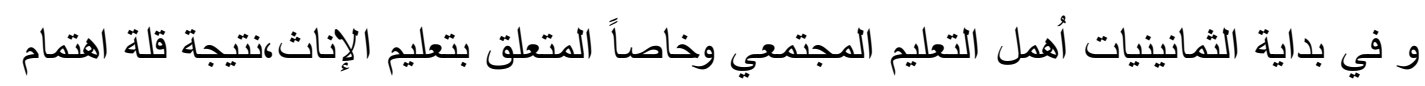
الإدارة التعليمية بالمتابعة والإشراف علية وقلة وعى بعض المسئولين وأولياء الأمور ،ومع بداية

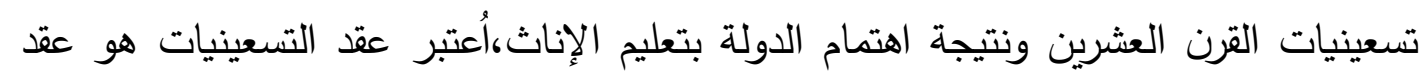
محو الأمية في مصر ،وكانت البداية فى أربع فصول بأربعة نجوع في منفلوط وأسيوط ،هدفها

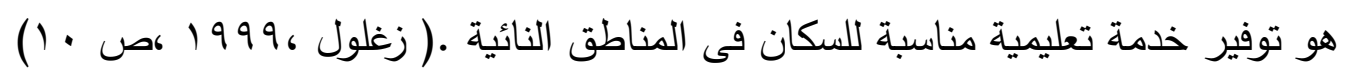




$$
\text { الجزء الأول • ع أكتوبر r. }
$$

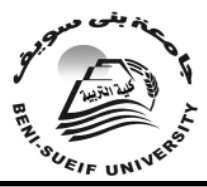

و فى هذا التوقيت كان اهتمام الدولة بالتعليم المجتمي كبير جداً تُوج بصدور القرار الوزاري رقم ب00 لسنة س99 19 بإنشاء .... مدرسة ذات الفصل الواحد للفتيات (قرار وزارى رقم

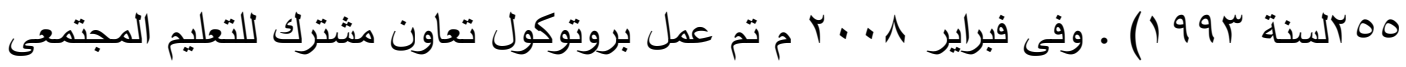
بين وزارة التربية و التعليم و المجلس القومى للطفولة و الامومة ـ ـ وعلى ذلك فى • ب نوفمبر

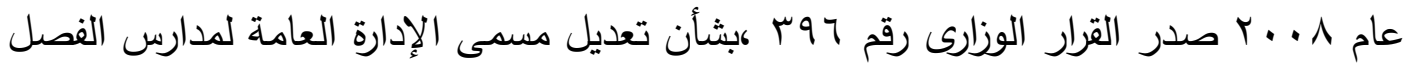

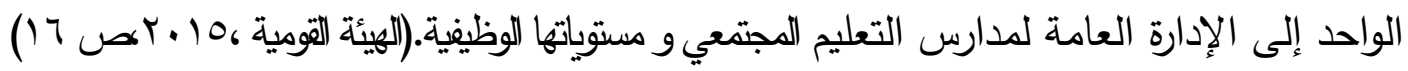

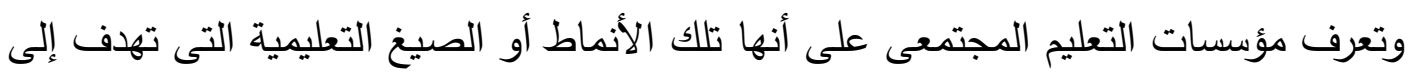
مد الخدمة التعليمية إلى أطفال القرى والنجوع والكفور والعزب والمناطق العشوائية والنائية ،الذين لم تتح لهم فرصة الإلتحاق بالمؤسسات التعليمية أو الذين التحقوا و تسربوا منها وبخاصة الفتيات

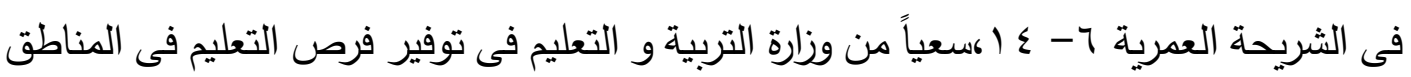

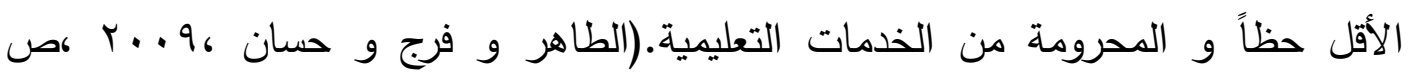

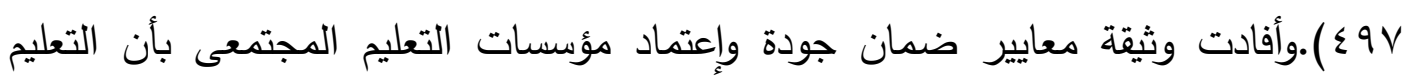

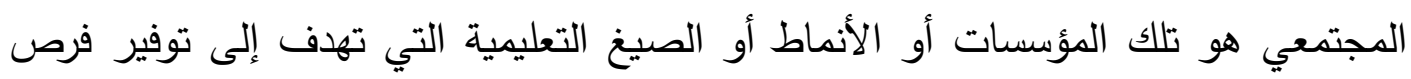
التعليم للأطفال المحرومة من الخدمات التعليمية في مصر في المناطق البعيدة و النائية و

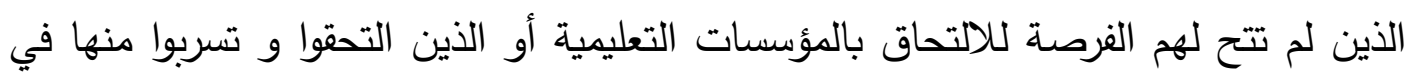
الشريحة العمرية من سن 1-؟ ا سنة اعتمادا على مشاركة المجتمع.(الهيئة القومية لضمان

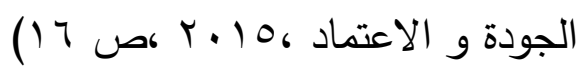

ومما سبق يمكن تعرف مدارس التعليم المجتمى على أنها "مدارس مكونة من فصل واحد تضم

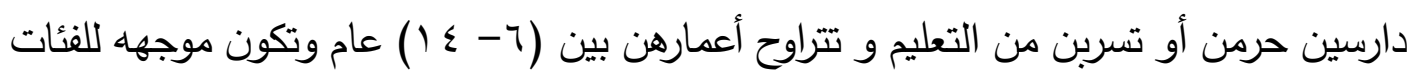
المهمشة والأماكن الريفية والنائية بحيث تدرس فيها كل المستويات فى مكان واحد و تدرس فئر فيها نفس مقررات المدارس الإبتدائية بالإضافة إلى التكوين المهنى و المشروعات الإنتاجيه و الصيفية التى تخدم البيئة المحلية". المحور الثانى:- فلسفة و أهداف التعليم المجتمعي 


$$
\begin{aligned}
& \text { عدد أكتوبر }
\end{aligned}
$$

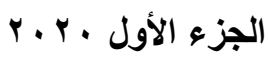

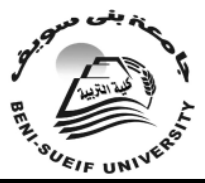

تقوم فكرة المدارس المجتمعية على استيعاب الأعداد الكبيرة من التلاميذ مع اختلاف أعمارهم

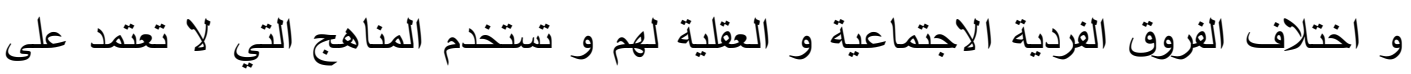
التلقين بل على الأنشطة الإيجابية وورش العمل و استخدام خامات من البيئة المحلية لكي تصبح المدرسة قادرة على تأهيل جيل من المتعلمين قادر على المنافسة في سوق العمل لتخدم

مجتمعه. (FREDENBURG, 1999,P.55)

لقد أوضحت الهيئة القومية لضمان جودة التعليم و الاعتماد لمؤسسات التعليم المجتمعي

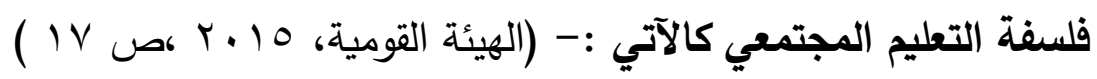

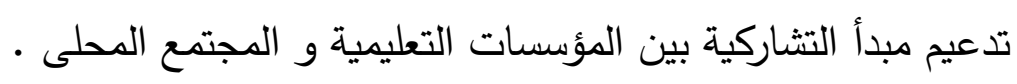
ربط المناهج بحياة المتعلمين اليومية و المجتمع و القضايا القومية والعالمية لتئية استخدام البيئة و مواردها لخدمة العملية التعليمية عدم التمييز بين الذكور و الإناث في تكافؤ الفرص التعليمية الحد من تسرب المتعلمين

مشاركة قيادات المجتمع المحلى في لجان التعليم ،وحل بعض المشكلات التي تواجه هذه المؤسسة . أهداف مدارس التعليم المجتمعي لا أحد ينكر أهمية دور التعليم المجتمي في تقليل نسب الأمية و التسرب من التعليم و كونه أكثر ملائمة و قبولاً لمجتمعات بعينها و أطفال بعينهم لا تصل إليهم الخدمة التعليمية أو حرموا أو تسربوا من التعليم علاوة على أطفال الشوارع الذين منعتهم ظروفهم للذهاب إلى المدرسة لوانة

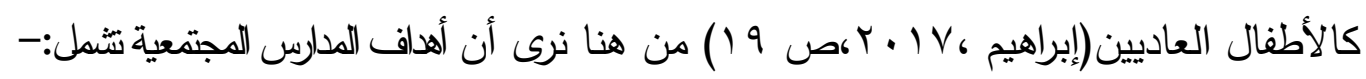
أولاً:- أهداف اجتماعية و خلقية تؤكد هذه المدارس على اكتساب التلاميذ مهارات التفاعل الإجتماعى و تعديل السلوك الإجتماعى وقبول الآخر و التكيف معه و معرفة فن الحوار الجيد و عدم التعصب ، حتى يتمكنوا من مواصلة الحياة اجتماعيا و خلقياً. ثانياً:- أهداف اقتصادية و سياسية يتضمن هذا الهدف إكساب التلاميذ مهارات العمل والإنتاج و إقامة المشروعات الصغيرة للمساهمة فى تتمية مجتمعاتهم لضمان اندماجهم اقتصاديا

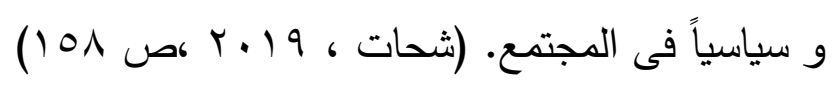




$$
\begin{aligned}
& \text { عدد أكتوبر }
\end{aligned}
$$

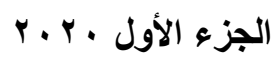

ثالثاً:- أهداف ثقافية تعليمية تتضمن وتؤكدعلى قبول التلاميذ المتسربين من التعليم تخفيضاً لمعدلات الأمية من ناحية وإنقاذاً لهؤلاء الطلاب من الفشل من ناحية آخري.وكل هذا كان بهدف عام واحد هو تعزيز قدرات مدارس التعليم المجتمي فى تنمية وتمكين المجتمعات المحلية

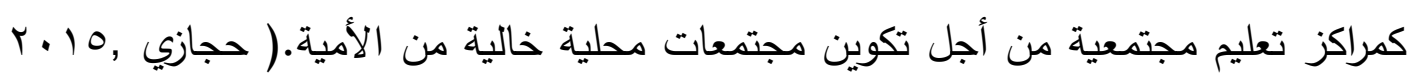

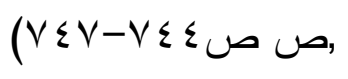

المحور الثالث :- صيغ التعليم المجتمعي

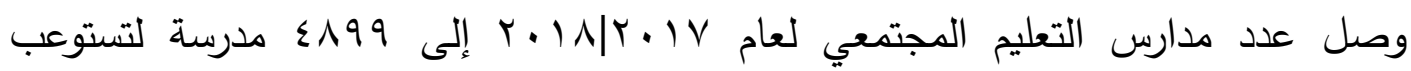

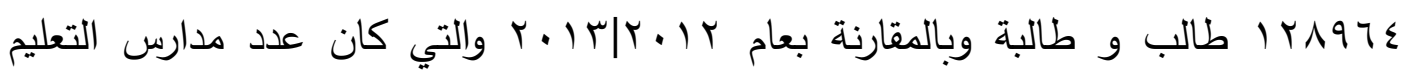

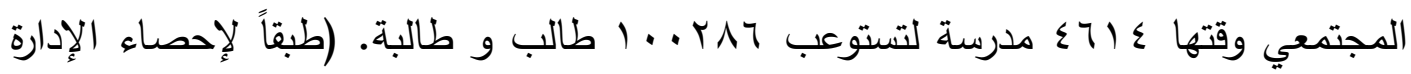
العامة لنظم المعلومات بوزارة التربية و التعليم).وتتمثل صيخ التعليم المجتمعي فى الآتى:-

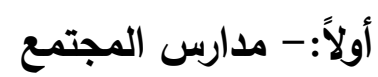
تم إنشاؤها في عام 999 ا في ثلاث محافظات بصعيد مصر و هي (أسيوط - سوهاج - قنا)

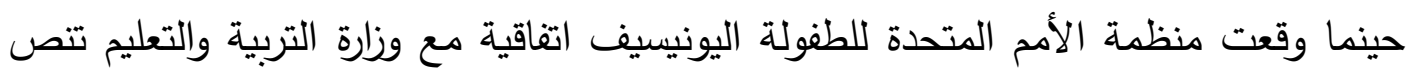
على أن قطاع التعليم في اليونيسيف سيصمم نموذجاً لمدارس المجتمع فى الأماكن المحرومة

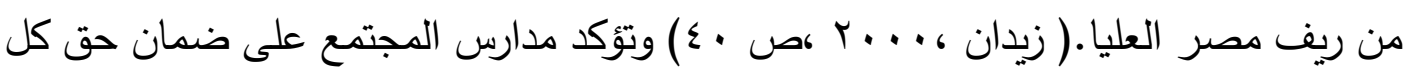

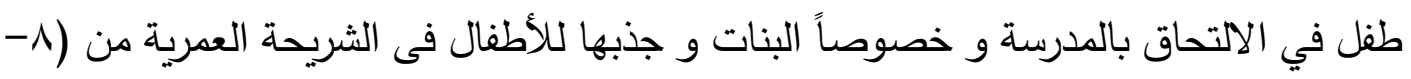
ع ( ) سنة , و يمكن قبول التلاميذ من سن السادسة الذين حالت ظروفهم الالتحاق بالمدرسة الابتدائية و تتيح الفرصة أيضاً للأطفال الذين يعملون للالتحاق بها نظراً لمرونة توقيتها. (هيكل

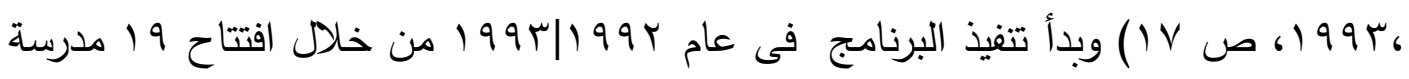
في عزب و نجوع تابعة لمركز منفلوط بمحافظة أسيوط ،كما تم افتتاح 7 مدارس في نجوع

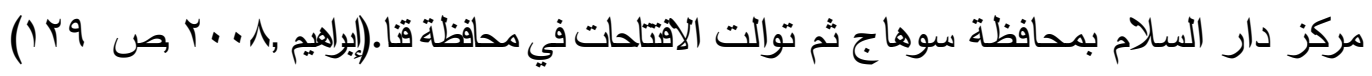
ثانياً:- مدارس الفصل الوراحد إذا تطرقنا إلى الخلفية التاريخية لمدارس الفصل الواحد منذ نشأتها فى عام • ب9 19 لوجدنا أنها مرت بثلاث مراحل على التوالى :-بدأت المرحلة الأولى من ( • 9 ام - 9 (19 م) ثم المرحلة 


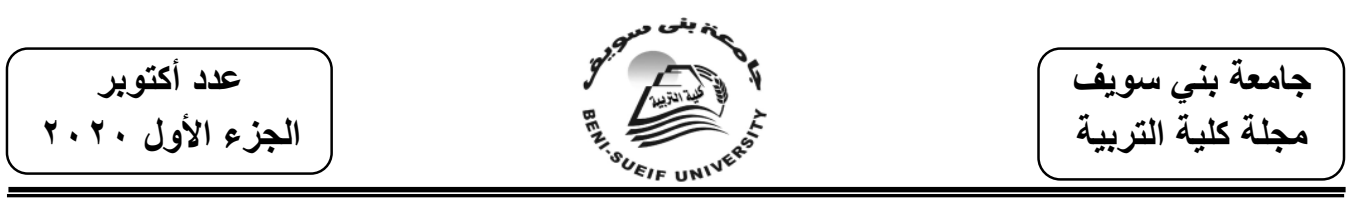

الثانية من (9V0 ام-999 (م) ثم المرحلة الثالثة من (r99 (م) إلى الآن .وتقوم فلسفة مدارس الفصل الواحد على مجموعة من الركائز :أولاً الركائز التربوية :-- من خلال تدعيم مبدأ القضاء على الأمية والتسرب وإستيعاب الفتيات

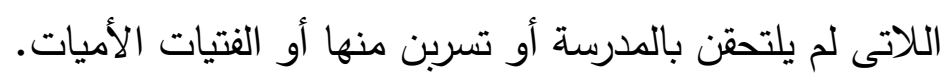

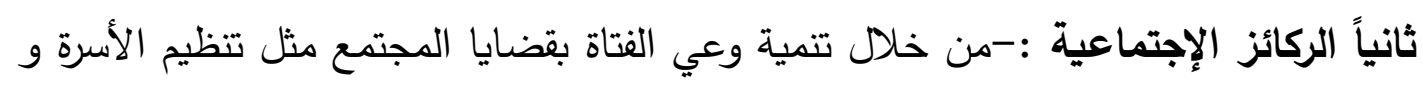
تربية الأبناء و الوعى الصحى و أساليب التغذية السليمة والإدخار والتلوث البيئى ...وغيرها ،بالإضافة إلى تحرير الفتاة من قيد العجز الفكرى و المهنى . ثالثاً الركائز الإقتصادية :-الإرتقاء بالمستوى الإقتصادى للريف المصرى عن طريق مساهمة الدارسين فى المشروعات الأتاجية المختلة بحيث تكون القرية مصدرة لمعظم السلع و المنتجات و ليست المستهكة.

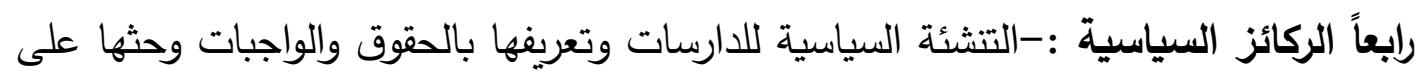

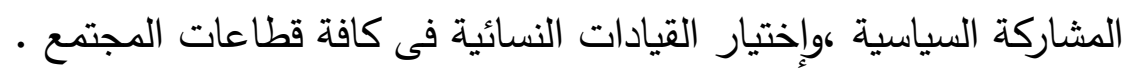
خامساً الركائز البيئية :-عن طريق ربط التعليم بالبيئة المحيطة،هما يؤدى إلى فهم البيئة

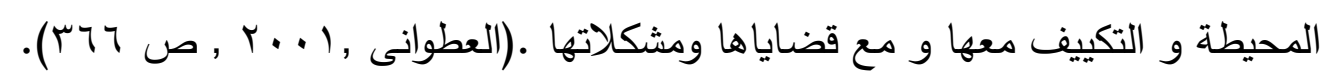

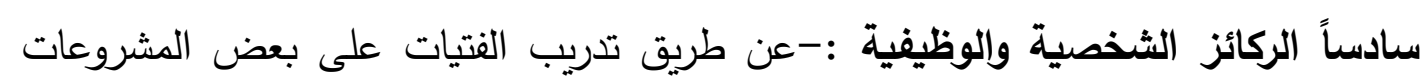

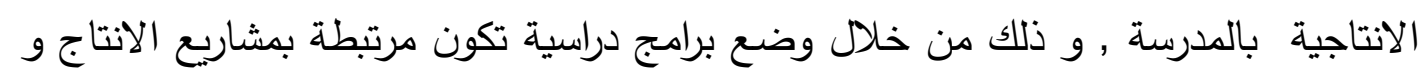

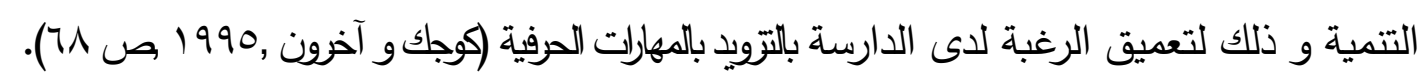
ثالثاً:- المدارس الصديقة للفتيات تم إنشاء هذه المدارس في عزب و نجوع المناطق النائية و المحرومة من الخدمة التعليمية على أرض أملاك الدولة ،و تتكون من حجرة دراسية واحدة تسع نحو هب إلى بـ ب تلميذ ،وتسمح

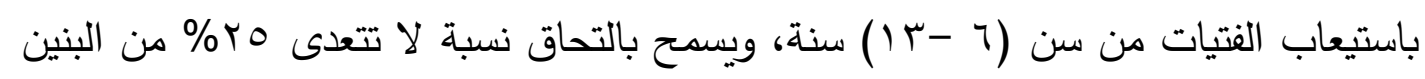
إذا ثبت احتياجهم للتعليم . National council for childhood,2004,p.2) وتقبل هذه المدارس الفتيات غير الملتحقات أو المتسربات من التعليم فى المناطق الفقيرة و المحرومة من

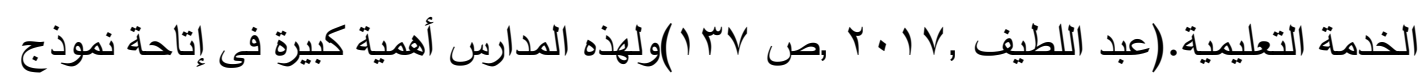
جديد صديق للفتيات على مسافة آمنة لهن فى جميع التجمعات السكانية ،وتحقيق مجانية التعليم 


$$
\text { الجزء الأول ـ ع أكتوبر r. }
$$

الأساسى روكسر المانع المالى لإقامة المدارس فى المجتمعات المحلية و ضمان إستمرارية البنات فى التعليم.(المجلس القومى للطفولة و الأمومة ، ه . . r ،ص ا ا-ب I) رابعاً:- المدارس الصديقة للأطفال في ظروف صعية

ظهرت هذه المدارس فى عام ب . . r تحت إشراف المجلس القومى للطفولة والأمومة وكان ذلك طبقاً لوصول عدد أطفال الثوارع وقتها إلى ما يقرب من مب ألف طفل و طفلة ،وكانت هذه المدارس تهدف إلى إعادة الأطفال الذين تسربوا من النظام التعليمى إلى سوق العمل أو الذين ليس لديهم مأوى عائلى ويعيشون فى ظروف صعبة ،وذلك لإتاحة الفرصة لهم لإستكمال تعليمهم فى المدرسة العادية مثل أقرانهم كوتقوم اليونسكو بالاشتراك مع وزراء التربية والتعليم

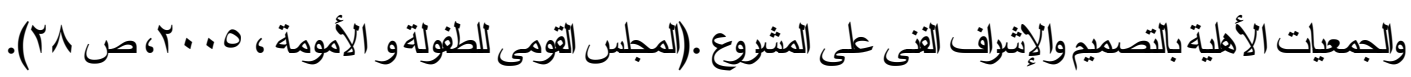
خامساً:-- المدارس الصغيرة

و قد تم إنشائها عام 99 V فى محافظتي الفيوم و سوهاج ،بإشراف هيئة كير الدولية ووزارة التربية و التعليم و جمعيات تتمية المجتمع ،وكان دور هيئة كير الدولية هو إختيار المكان و و تأهيل الميسرات و تشكيل مجالس الأمهات وتتظيم حمالات توعية للأهالى و توفير الأثاث . أما دور وزارة التربية و التعليم توفير الكتب ودفع أجور الميسرات وتوفير التغذية والتأمين الصحى • أما عن جمعيات تتمية المجتمع فدورها تجميع شهادات ميلاد الأطفال وتوفير مبنى للمدارس

والخامات اللازمة للتدري. (الهيئة القومية، 10 • ب ،ص r r ) المحور الرابع:- واقع التعليم المجتمعى فى محافظة الثرقية ومشكلاتها تعتبر محافظة الثرقية من أهم محافظات جمهورية مصر العربية نظراً لموقعها الهام و الفريد

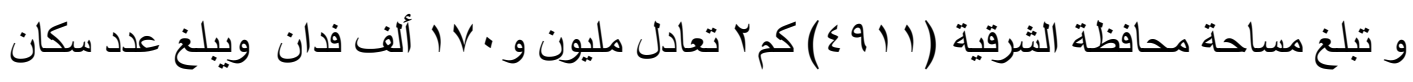

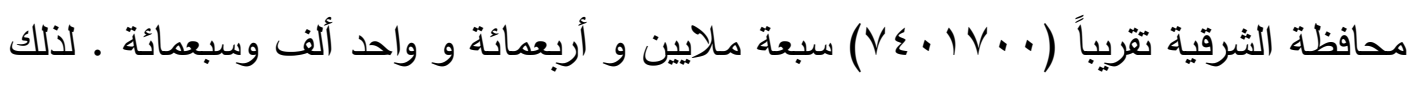
فهى ثالث محافظة فى تعداد السكان على مستوى الجمهورية بعد القاهرة و الجيزة, و يغلب عليها الطابع الريفى.(الجهاز المركزى للتعبئة العامة والأحصاء ، 19 . بكصع ع- 0).و تمتاز بتنوع إمكاناتها و تتوع أنشطتها الزراعية والمعدنية والتعدينية والصناعية والسمكية والسياحية

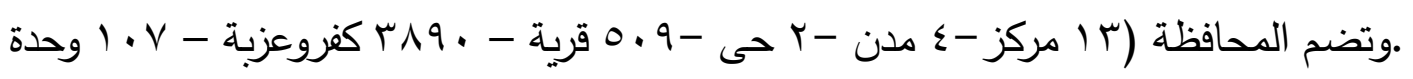




\section{عدد أكتوبر

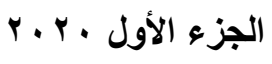

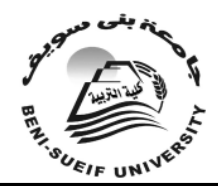

جامعة بني سويف الترية مجلة كلية التربية

محلية).(إدارة الوحدات المحلية بمحافظة الشرقية 9 1 • ب)ويبلغ عدد الإدارات التعليمية بها ـr ب

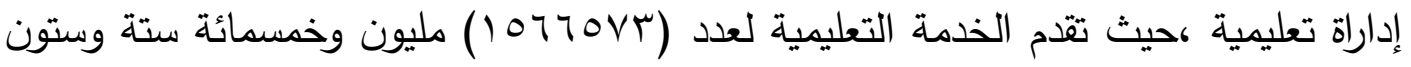
ألف وخمسمائة و ثلاثتة و سبعون طالب وطالبة من خلال (T/Y\&) مدرسة.(طبقاً لإحصاء

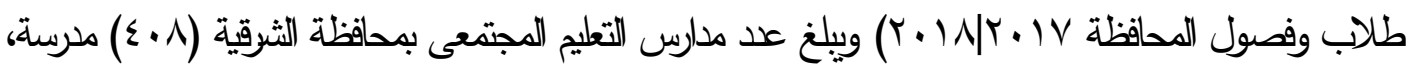

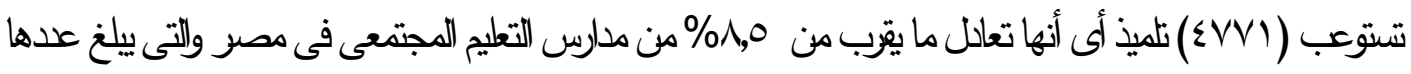

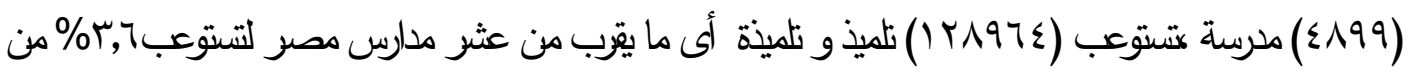

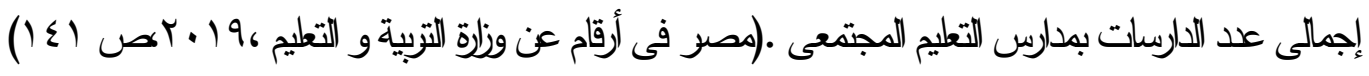
والجدول التالى يوضتح إحصاء بأعداد الطلبة وأعداد الفصول والتلاميذ وأعداد الإسبين و المتسببن فى

الإدارات التعليمية للتعليم المجتمعى بالمحافظة حتى تاريخ (-9-9 1 ـ (مليرية التتبية والتعليم بالثرقية 9 ( ـ ץ)

\begin{tabular}{|c|c|c|c|c|c|c|c|c|c|c|}
\hline \multicolumn{3}{|c|}{ الاجمالى } & \multicolumn{6}{|c|}{ الفصل الواحد } & \multirow[b]{2}{*}{ الإدارة } & \multirow[b]{2}{*}{ s } \\
\hline الراسبين و المتسربين & التلاميذ & الفصول & الصادس & الخامس & الرابع & الثالث & الثانى & الصف الاول & & \\
\hline 7 & TVT & $r \varepsilon$ & $V V$ & Irr & זr & 10 & r & 7 & شرق & 1 \\
\hline$r$ & 178 & rr & ro & $r$. & $r$. & r & $r$. & $r$. & غرب & $r$ \\
\hline$\varepsilon$ & M. & ro & $V \varepsilon$ & VI & vi & 00 & r & $\wedge$ & منيا القـح & $r$ \\
\hline 11 & $1 \ldots v$ & vi & r10 & $r \leq r$ & ri. & 111 & 1.9 & $\leq 9$ & بلبيس & $\varepsilon$ \\
\hline$\varepsilon$ & IrT & ir & $r \varepsilon$ & rV & r & 17 & 19 & $1 \varepsilon$ & ديرب نجم & 0 \\
\hline 7 & oor & rq & $1 . \varepsilon$ & $1 \varepsilon$. & 91 & $\wedge$ & $7 \varepsilon$ & 7. & فاقوس & 7 \\
\hline$\varepsilon$ & $r \cdot v$ & rI & rv & 09 & 19 & 10 & rt & 10 & الحسينية & v \\
\hline 11 & $\varepsilon .9$ & ro & 10 & $\wedge$. & 97 & $\vee q$ & o. & 19 & ابو حماد & $\wedge$ \\
\hline$\varepsilon$ & INV & ro & 7. & $\varepsilon r$ & rq & r & 1. & 。 & هويا & 9 \\
\hline 9 & Y10 & rr & $\varepsilon r$ & $\leq 7$ & $\varepsilon \wedge$ & $\varepsilon \varepsilon$ & 19 & 17 & ابو كبير & 1. \\
\hline$\varepsilon$ & INT & 19 & $\leq 7$ & זי & ro & rA & 11 & 9 & كفر صقر & 11 \\
\hline 0 & rar & ir & o. & or & $\varepsilon \varepsilon$ & $\leq 9$ & $\sum \wedge$ & $\leq 0$ & اولاد صقر & ir \\
\hline r & $1 \ldots$ & 11 & rA & rq & TV & $\wedge$ & v & 1 & الابراهيمية & 15 \\
\hline 1 & $0 \leqslant$ & $\varepsilon$ & $r$. & 11 & 17 & . & . & . & القرين & $1 \leq$ \\
\hline$r$ & 177 & 9 & $\leq 7$ & \&1 & «1 & rT & 7 & 1. & مشتول & 10 \\
\hline . & $7 \varepsilon$ & 0 & . & . & $\varepsilon$ & $r$. & $1 \varepsilon$ & 17 & العاشر & 17 \\
\hline
\end{tabular}




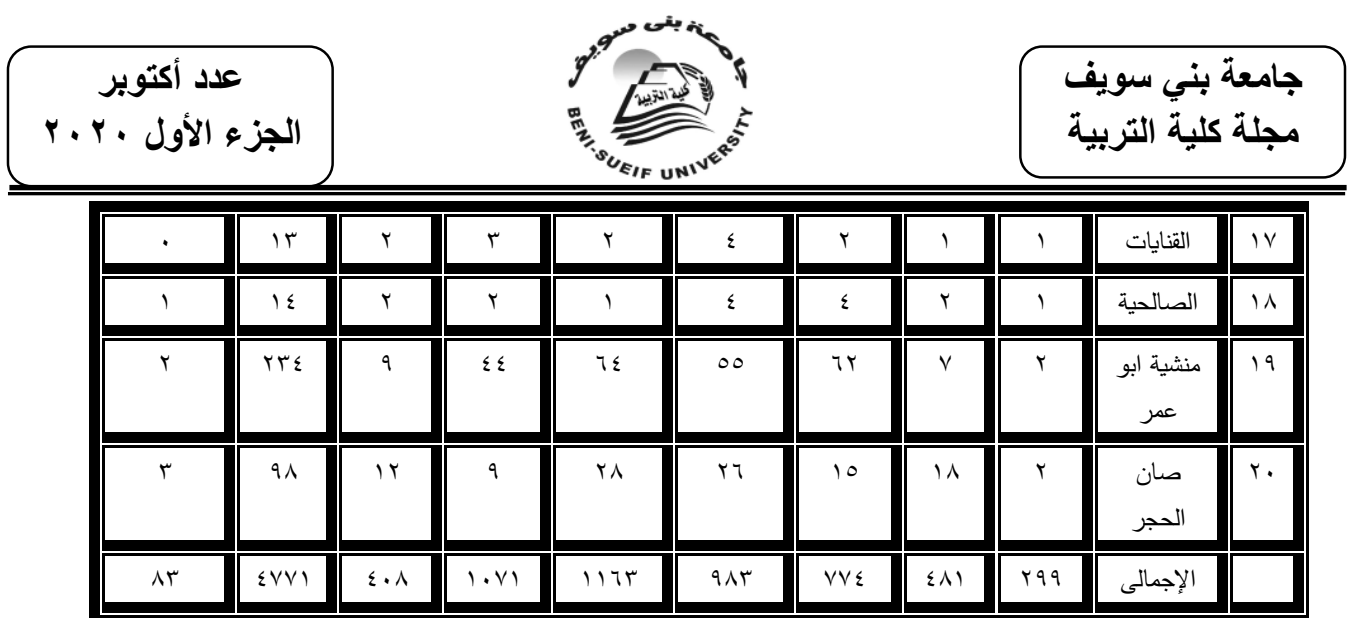

من الجدول السابق يتضح أنه يوجد عدد كبير من مدارس الفصل الواحد بمحافظة الثرقية وصلت إلى 1 •ـ مدرسة .وتعتبرإدارة بلبيس التعليمية من أكبر الإدارات التى تحتوى على

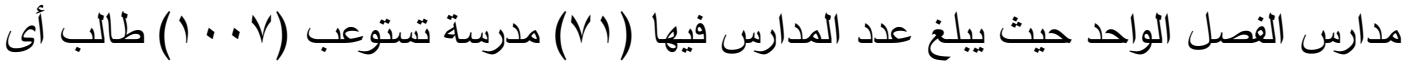
ما يعادل §؟\% من عدد الدارسين فى المحافظة لذلك فإن إدارة الحسينية تحتوى على ربع عدد الدارسين فى المحافظة ويليها إدارة أبو حماد. بينما جاءت إدارة الصالحية والقنايات الأقل من حيث عدد المدارس,ليصل عدد التلاميذ فى كل منهما ؟ ا تلميذ،فهى مدينة صناعية يفضل أولياء الأمور ذهاب أولادهم للعمل بالمصانع عن إتمام دراستهم .وفى إدارة أولاد صقر يوجد عدد (Y I ) مدرسة تغطى مركز أولاد صقر و تعمل هذه المدارس فى عدد (9) مبانى مدرسية

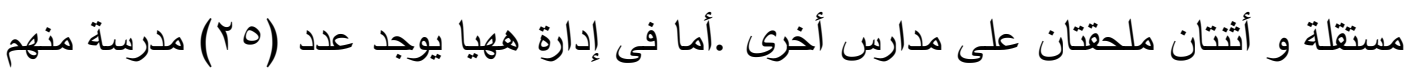
(ع)حضر-(Y) (Y) بالريف.(إدارة التخطيط والمشروعات مديرية التربية والتعليم بالثرقية

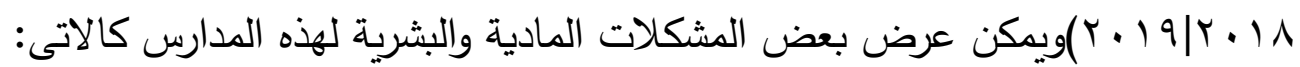
عدم توافر أدوات الإقتصاد المنزلى وتلف بعض الأجهزة كالثلاجات والبوتاجازات وماكينات الخياطة،وعدم كفاية أجهزة الحاسب الألى وكذلك التجهيزات التكنولوجية . تقع بعض المدارس على الطريق بجوار المقاهى والسيبرات وأكثالك الكهباء ووجود القمامةو بعض النفايات أيضاً بجانب سور العلي من المداس.(مليرية التزبيةو التعليم بالثرقية 9 ( ب )

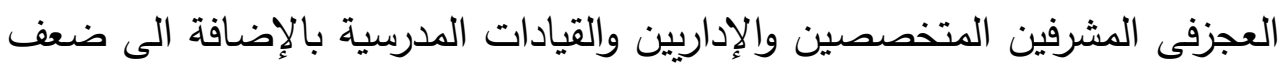
مستوى التحصيل للتلاميذ وغياب التلاميذ المتكرر مع وجود عجز كبير فى الأخصائيين الاجتماعيين والنفسيين وكذلك فى الإداريين وعمال الخدمات و النظافة مما يؤثرعلى

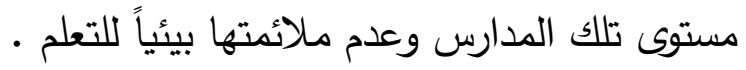




$$
\begin{aligned}
& \text { عدد أكتوبر }
\end{aligned}
$$

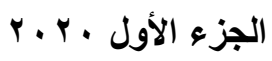

ضعف الوعى المجتمعى بأهمية مدارس الفصل الواحد و ضعف المشاركة المجتمعية الإيجابية من المجتمع المحيط . ضعف دور الجمعيات الأهلية ومؤسسات المجتمع المدنى فى المساهمة فى تطوير

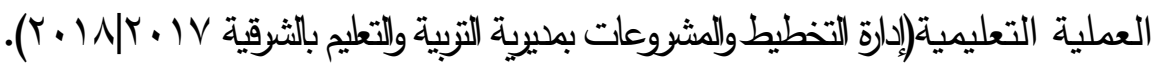
الفصل الرابع الجودة فى التعليم

\section{المحور الأول :-مفهوم الجودة}

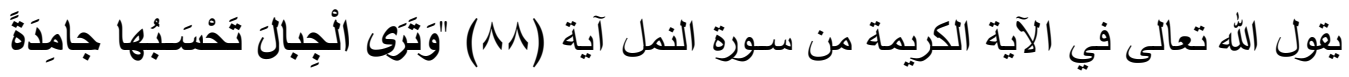

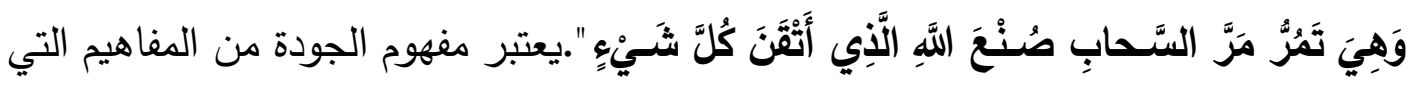

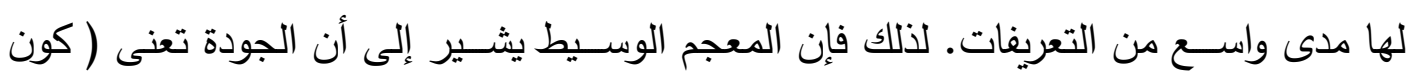
الثيء جيدا) والفعل جاد ،و أن الكيفية مصدر صناعي من لفظ كيف و كيفية الثيء تعنى الثي صـــفته.(المعجم الوســـيط رص 0 ؛ 1 ). وقد تعددت نظرة العلماء لمفهوم الجودة في التعليم

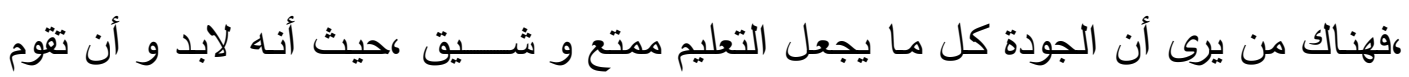
المدرسـة بتقديم تعليما يتسـم بالجودة و تجعل الطلاب مشـاركين بشكل ايجابي و اشتياق دائم

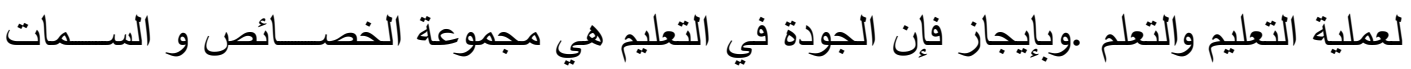

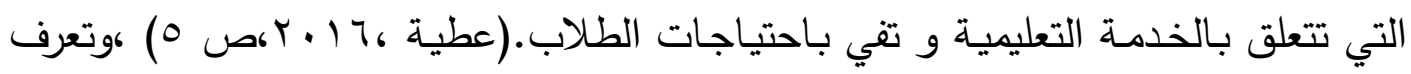
أيضـاً على أنها مجموعة من الخصـائص والمواصفات التي يجب توافي وافرها في النظام التعليمي

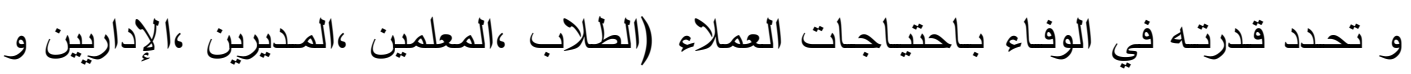
المجتمع المحلى ) من الخدمة التعليمية المقدمة .و تكون هذه الخصـائص والمواصفات بمثابة

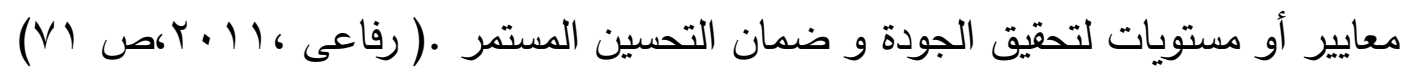
وقد تتاولت مديرية التربية والتعليم بمحافظة الثــرقية محور الجودة على أنها تحســين جودة فعالية الخدمة التعليمية ،من خلال توفير منهج معاصـر ،وتكنولوجيا موظفة بكفاءة ،وأنثـطة تربوية رياضــية وغير رياضــية ،ومعلم فعال لكل طفل في كل فصـلـل ,وقيادة فعالة في كل مدرســـة ،و فرص للتمية المهنية الداخلية والخارجية لكل معلم وإداري ليتقدم ويتميز ـ(إدارة

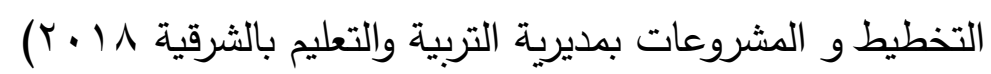




جامعة بني سويفة

\section{و يتضمن مفهوم الجودة في التعليم}

- المواهب والقدرات والخبرات التي يمتلكها الفرد الذي يعمل في المؤسـســة التعليمية و مدى التعاون بين الأفراد في العمل

- الاستمرار في تحسين جودة المخرجات العلمية والتعليمية والحرص الدائم عليها . - الحرص على تقليل الأخطاء الممكنة لكي يؤدى العمل بطريقة صـيحة مع الحصـول على رضي المستفيدين من العملية التعليمية . - العمل على حسـاب تكاليف الفرص الضــائعة وتكلفة الأخطاء وعملية التقويم لمعرفة تكلفة الجودة داخل المؤسسة التعليمية . - التركيز على (الأهداف - الإجراءات- الهيكل التنظيمي- أســـاليب العمل و طرقه -

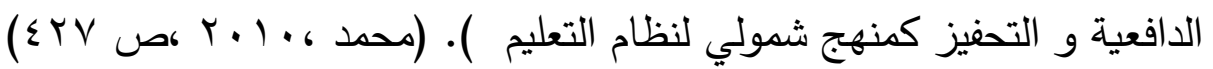
المحور الثانى :-أهمية الجودة ومعاييرها يمكن عرض أهمية الجودة في النقاط التالية :- الجودة بمثابة أداة فعالة للتمية المهنية للمعلمين وتعمل على توفير مؤشــــرات الأداء

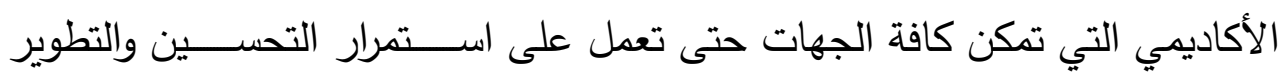

$$
\text { لتحقيق الأهداف المرجوة . }
$$

- تعتبر جودة التعليم أسـاس من ركائز ودعامات إستراتيجيات الإدارة التربوية الحديثة و التحسين المستمر في المنتج التعليمي و مخرجات العملية التعليمية ،والعمل على رفع كفاءة العاملين في العملية التعليمية وذلك لضـــــان تخريج عناصــر تمتلك المعارف الأساسية التي تجعلهم قادرين على المنافسة في كافة المجالات العملية بكفاءة عالية - - توفير الأدوات والأساليب المتكاملة التي تساعد المؤسسات التعليمية على تحميق النتائج المرجوة. - تمكين كاقة الإدارات وصانعي القرار من الوقوف على مؤشرات القوة والضعف داخل المؤسسة التعليمية

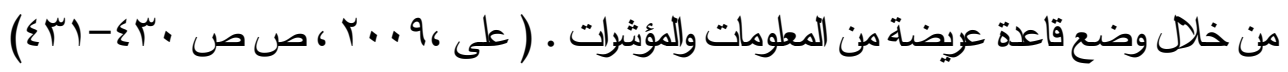

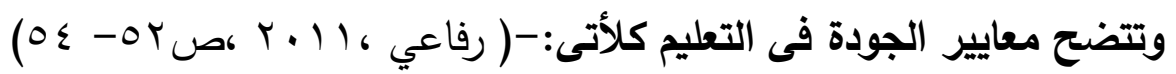
أولاً : قيادة تعليمية قوية و حازمة . 
ثانياً :- مناخ اجتماعي وعلاقات إيجابية بناءه داخل المؤسسة . ثالثاً :- التركيز على عملية التعليم و التعلم و تحقيق مستويات عالية من الانجاز • رابعاً:- تحقيق الجودة و ترسيخ مبدأ المحاسبية

المحور الثالث:- معايير ضمان جودة التعليم واعتماد مؤسسات التعليم المجتمعي أهمية معايير اعتماد مؤسسات التعليم المجتمي/(لهيئة القومية لضمان جودة التعلي،، 1 ـ بحهب) ا ـ تطبيق الرؤية والرسالة التي وضعتها مؤسسات التعليم المجتمعي لنفسها r. الحرص على الالتزام بمبدأ المحاسبية ومبدأ المساءلة وعملية الثقويم الذاتي والثقويم المستمر . r. الالتزام بتفعيل دور المؤسـسـات المحلية , و مسـاعدة جهات المراقبة و المتابعة على لعى

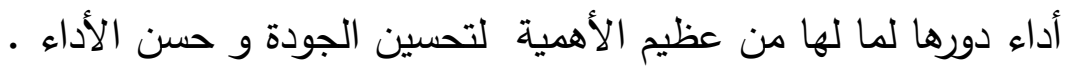
ع. تحســين الفاعلية التعليمية بتحديث طرائق التعليم و التعلم ,المتمركزة على المتعلم رو ربط التعليم بالمهارات الحياتية وإدارة الحياة واحتياجات المجتمع المحلى • ه. تحسين و تطوير أساليب الأداء و التقويم المؤسسي و التعليمي •

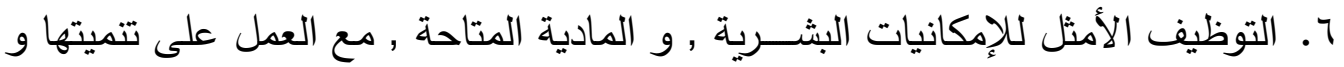

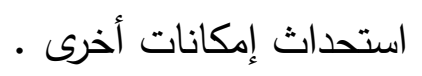

\section{احتياجات التعليم المجتمعي في محور الجودة}

أولاً من الجـانب المـادي(الخطط التنفيذيـة لجميع البرامج التعليميـة لمحسافظـة الثــــرقيـة

$$
(r \cdot 19 / r \cdot 11
$$

- الحاجة إلى إنتاج الوجبات الغذائية محلياً و توزيعها على مدارس التعليم المجتمعي - تفعيل نظام التأمين الصحي بالمحافظة لطلبة مدارس التعليم المجتمي ل - الحاجة إلى تزويد مدارس الفصل الواحد بأجهزة كمبيوتر بالإضافة إلى عمل إحلال و

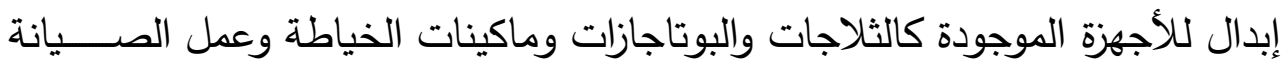
اللازمة لتلك الأجهزة بصفة دورية . - الحاجة إلى إنشاء مكتبات خاصة لتلك المدارس ل 


$$
\begin{aligned}
& \text { عدد أكتوبر }
\end{aligned}
$$

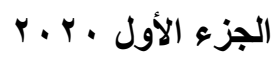

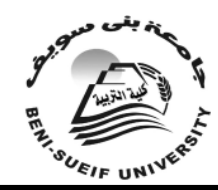

\section{جامعة بني سويف كايفة} مجلة كلية التربية

\section{ثانياً من الجاتب البشرى}

- الحاجـة إلى تدعيم الإدارة المحلية من( وحدات محلية و قرويـة- و مراكز المدن و الح

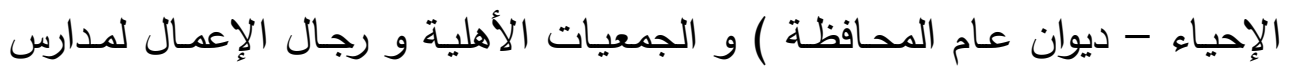
الفصل الواحد و توفير ما ينقصها من إمكانيات مادية . - الحاجة إلى تفعيل برامج تتمية مهنية مســـدامة لعدد كبير من المعلمات والموجهين على أســلوب تعليم القراءة والحســـاب والأســـاليب الحديثة في التعليم (تقافي مهني )وأساليب التقويم المستمر وطرق التعلم النشط التي تتاسب مع طبيعة التعليم المجتمعي . وتبذل مديرية التربية والتعليم بالمحافظة قصارى جهدها وتتطلع لوضـع رؤية مستقبلية

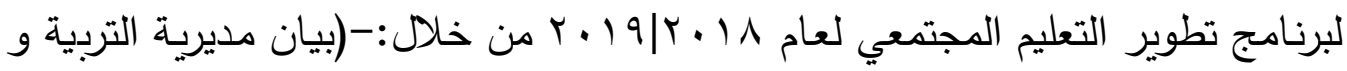

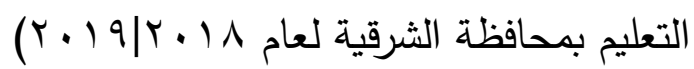

ا- مد الخدمة التعليمية للمناطق الأكثر احتياجاً و خاصاً القرى والنجوع • r- مقاومة بعض العادات و التقاليد التي تحد من تمكين الأطفال من التعليم •

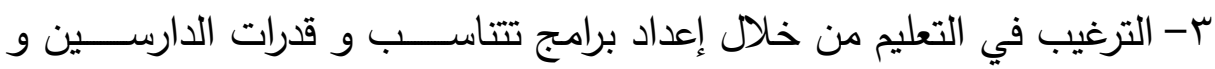
ظروفهم و تمكينهم للاستفادة من المهارات الحياتية و التعليمية . ع - عقد المزيد من الندوات لتشـــيع كل من تســرب من التلاميذ على إعطائهم الفرصة الثانية للعودة إلى التعليم.

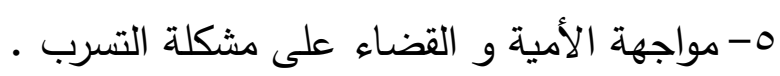

المحور الرابع:- تحديات تطبيق معايير الجودة و الاعتماد في مدارس التعليم المجتمعي بمحافظة الثرقية

و بالرغم من كل مواطن القوة التي تتمتع بها هذه المؤسسـات إلا أن الواقع يشير إلى أن هذه المؤسسات تواجه الكثير من التحديات لتطبيق الجودة فيها وأنها تعانى من صعوبة إلـان المناهج الغير ملائكة للطلاب وظروفهم وإمكانياتهم العقلية ونقص الموارد البشرية المؤهلة

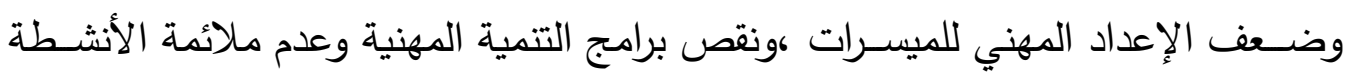

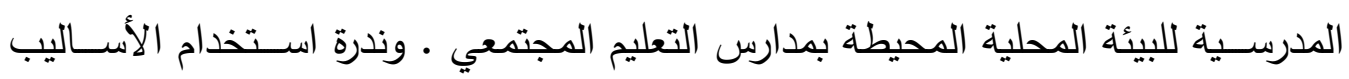




$$
\begin{aligned}
& \text { عدد أكتوبر }
\end{aligned}
$$

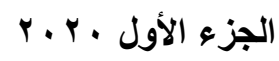

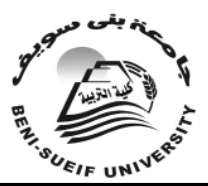

جامعة بني سويف كلف الترئة مجلة كلية التربية

الحديثة في العملية التعليمية داخل معظم المدارس وانخفاض مســتوى العملية التعليمية و ارتفاع معدلات التسـرب لاى الدارسـات لكثرة الغياب ،وقصــور عملية التوجيه والمتابعة ،والعجز في المخصـصــات المالية اللازمة للإنفاق على تلك المدارس لاسـيما الحكومية

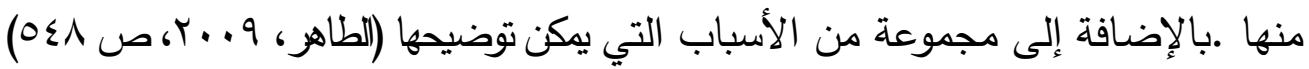
1- عـدم وعى أوليـاء الأمور بـأهميـة التعليم المجتمعي وأهميـة تعليم بنـاتهن

$$
\text { وضعف مشاركة النساء في حملات التوعية }
$$

r- تدنى المستوى الاجتماعي و الحالة الاقتصادية للارسات و تعد المشكلات الأسرية r-زواج الفتيات المبكر والذي يثكل تهديداً واضحاً وصريحاً في مواصلة الفتيات

لتعليمهن وخصوصاً في الريف والمناطق النائية .

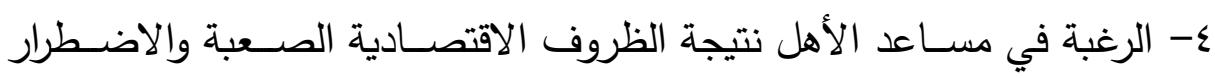
للعمل بدلاً من التعليم فالعمل يدر دخلاً كبيراً للأسر ذات الحالة المتنية اقتصادياو اجتماعيا

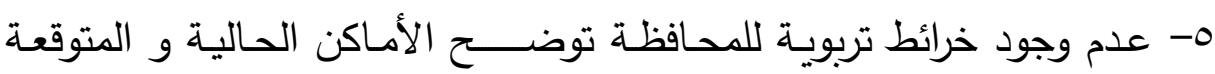
مستقبلاً لمدارس التعليم المجتمعي و الخطة الزمنية والتمويل اللازم .حيث أن المحافظة تعانى من عم وجود تحيد واضح للأماكن الأكثر احتياجا لفصول ومدارس التعليم المجتمعي . צ- عدم التسسيق بين مدرسي مدارس التعليم المجتمعي ومدرسي مدارس التعليم الاســــى المجاور نتيجة ضـعف التواصـل بين الميسـرات و المديرين و الموجهين بالتعليم المجتمعي مع نظرائهم من مدارس التعليم الاساسى لتبادل الآراء. الفصل الخامس الميدانى

\begin{tabular}{|c|c|c|c|c|c|c|}
\hline مستوى & 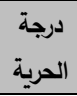 & مربع كاي & 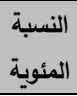 & التكرارات & الاستجابة & 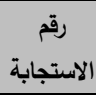 \\
\hline \multirow[t]{3}{*}{ 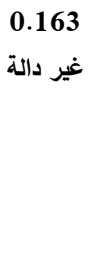 } & \multirow[t]{3}{*}{4} & \multirow[t]{3}{*}{6.526} & 10.5 & 2 & 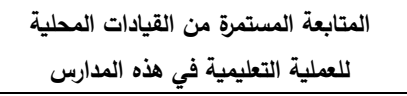 & 1 \\
\hline & & & 42.1 & 8 & إصدار قانون جديد للإدارة المحلية لتفعيل & 2 \\
\hline & & & 21.1 & 4 & 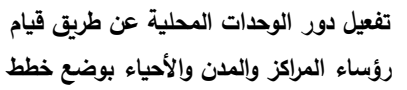 & 3 \\
\hline
\end{tabular}

ما مقترحات سيادتكم لتفعيل لور الإارة المحلية لتصسين جودة العملية التعليمية بمدارس التعليم المجتمعي ؟ 


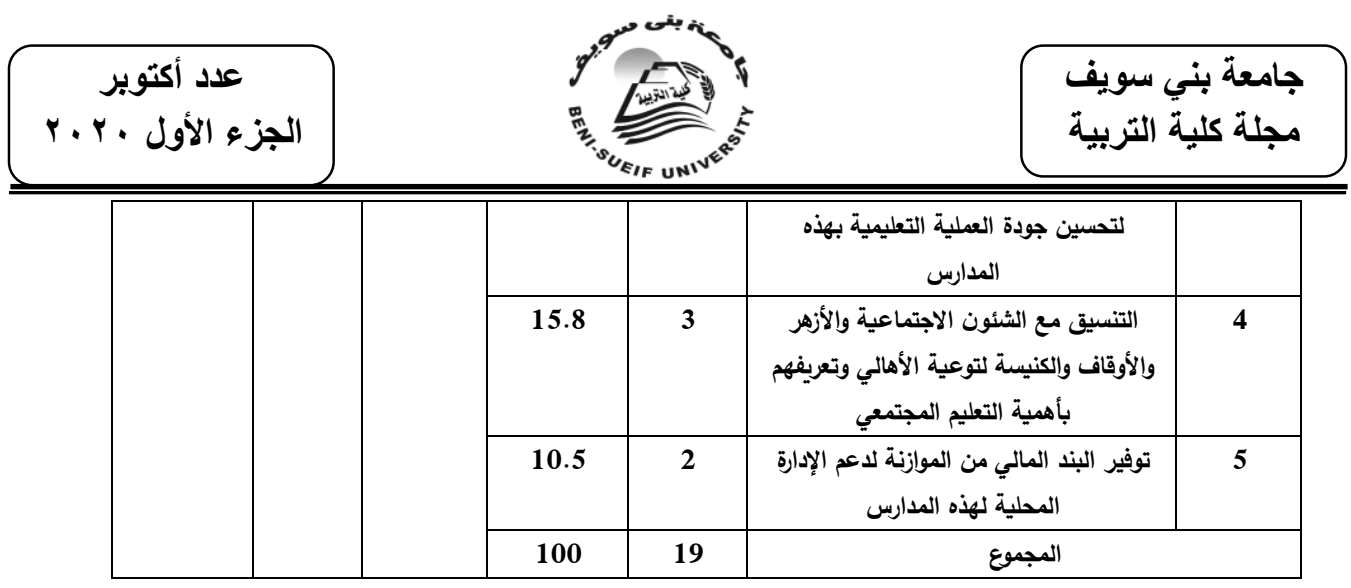

يتضـح من الجدول السابق أن استجابات عينة الدراسـة والتي بلغ عددها (19) من رؤساء

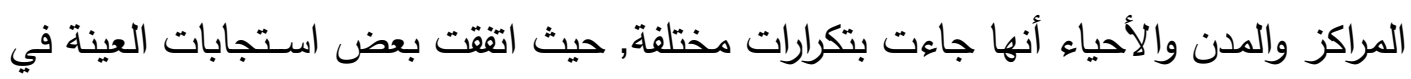

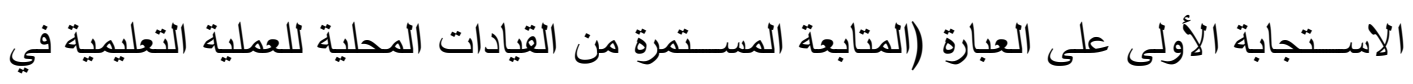
هذه المدارس) بتكرار (2) ، بنســبة مئوية (10,5\%). وهذا يعنى أن هذه النســبة من وجهة

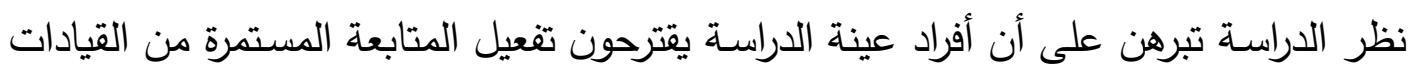

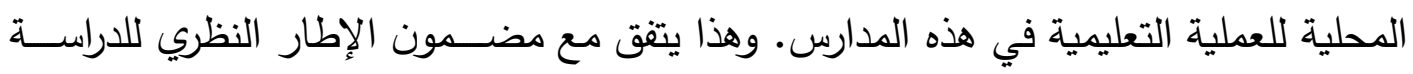
الذي جاءت به كثير من الدراسات السابقة وما أكته النتائج البحثية للراسة (مشيرة إيراهيم صابر 2017). واتفقت بعض اسـتجابات العينة في الاســتجابة الثانية على العبارة (إصــدار قانون جديد للإدارة المحلية لتفعيل دور اللامركزية) بتكرار (8) ، بنســبة مئوية (42,1\%) وهذا يعنى أن الن

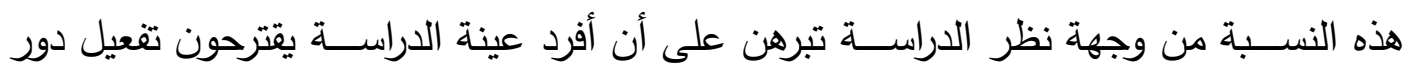

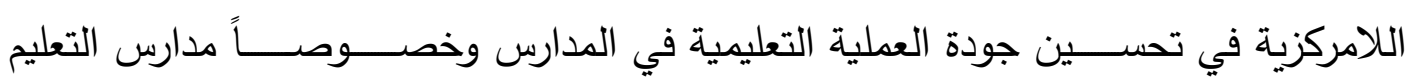
المجتمعي التي تهتم بأبناء البيئة المحلية وهذا يتفق مع مضدون الإطار النظري للدراسـة الذي جاءت به كثير من الدراسات السابقة وما أكدته النتائج البحثية للراسة (خالد صبيح تهامي 2013). واتفقت بعض اســتجابات العينة في الاســتجابة الثالثة على العبارة (تفعيل دور الوحدات

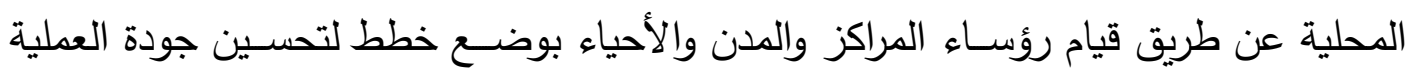
التعليمية بهذه المدارس) بتكرار (4) ، بنسـبة مئوية (21,1\%) وهذا يعنى أن هذه النسـبة من وجهة نظر الدراســة تبرهن على أن أفراد عينة الدراســة يقترحون تفعيل دور الوحدات المحلية

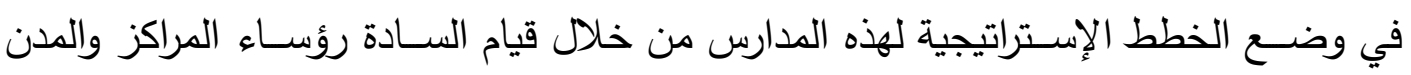
والأحياء بوضـع خطط بالتعاون مع مديرية التربية والتعليم لتحسين جودة العملية التعليمية لهذه 


$$
\begin{aligned}
& \text { عدد أكتوبر }
\end{aligned}
$$

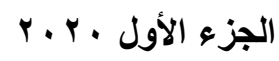

المدارس • وهذا يتفق مع مضدون الإطار النظري للدراسـة الذي جاءت به كثير من الدراسـات السابقة وما أكدته النتائج البحثية لدراسة (قوت القلوب النجار 2011). واتفقت بعض اســجابات العينة في الاسـتجابة الرابعة على العبارة (التسـيق مع الثـئون الاجتماعية والأزهر والأوقاف والكنيســــة لتوعية الأهالي وتعريفهم بأهمية التعليم المجتمعي) بتكرار (3) , بنسبة مئوية (15,8\%) وهذا يعنى أن هذه النسبة من وجهة نظر الدراسة تبرهن

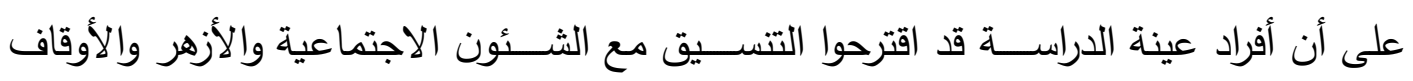
والكنيســـة لعمل حملة توعية للأهالي وتعريفهم بأهمية مدارس التعليم المجتمعي حيث أن هذه المدارس غير معروفة لشــريحة كبيرة في المجتمع. وهذا يتفق مع مضـــمون الإطار النظري للدراسـة الذي جاءت به كثير من الدراسـات السـابقة وما أكدته النتائج البحثية لدراسـة (فاطمة محمد بهجت 2015) ودراسة (عبد اللطيف بوعبداللوى2014). واتفقت بعض استجابات العينة في الاستجابة الخامسة على العبارة (توفير البند المالي من الموازنة لدعم الإدارة المحلية لهذه المدارس) بتكرار (2) , بنسـبة مئوية (10,5\%) وهذا يعنى أن هذه النسـبة من وجهة نظر الدراسـة تبرهن على أن أفراد عينة الدراسـة يقترحون توفير بند مالي من موازنة المحليات لتفعيل دور الإدارة المحلية في دعم هذه المدارس.. وهذا يتفق مع مضمون الإطار النظري للدراسة الذي جاءت به كثير من الدراسات السابقة وما أكته النتائج البحثية للراسة (هالة أحمد الجلاد 2008) ودراسة (آمال سيد مسعود 2008) و دراسة (محمد عوض البربري 2015). وباسـتقراء قيمة دربع كاى ودلالتها الإحصـائية لهذا السـؤال واسـتجابات عينة الدراسـة فقد جاءت بقيمة (6,526) وجاءت بدرجة حريـة (4) ,وغير دالة عند (0,163) وهذا يعنى أنه لا توجد فروق واضـحة بين الاستجابات برغم وضـوح هذه الفروق في النسـب المئويـة . وهذا يدل على أهمية جميع الاستجابات بغض النظر عن النسب المئوية الموجودةوأن هذه الاستجابات لو طبقت في ظروف زمنية لاحقة ستكون مثلها منلى هذه الاستجابات الحلية مما ييرهن على أهمية الأخذ بها جميعاً. في ضوء ما سبق عرضـه من تطبيق استمارة المقابلة، تناولت الاستمارة واقع دور الوحدات المحلية في مدارس التعليم المجتمعي وتناول أفراد العينة بعض الآراء والمقترحات لتفعيل دور الإدارة المحلية لتحسين جودة العملية التعليمية بمدارس التعليم المجتمعي كما يلي:- 


$$
\begin{aligned}
& \text { عدد أكتوبير }
\end{aligned}
$$

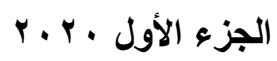

- مقلة عل عد الدارسات في مدارس التعليم المجتمعي يمنل مشكلة كبيرة من أهم المشكلات التي يجب معالجتها

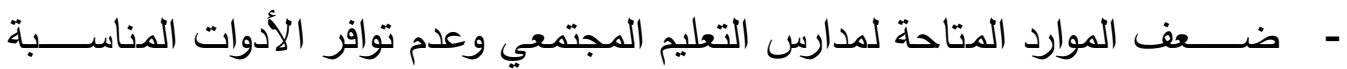
لمصادر التعلم الجاذبة للطلاب من أهم المشكلات التي يراها عينة الدراسة. - - قلة عدد عمال النظافة والأمن في مدارس التعليم المجتمعي •

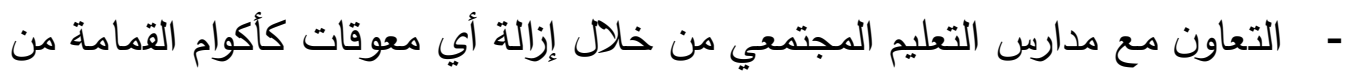

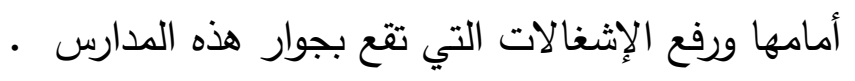

- المرور والمتابعة الدائمة الثـبه يومية على مدارس التعليم المجتمعي لأعمال الصـيانة

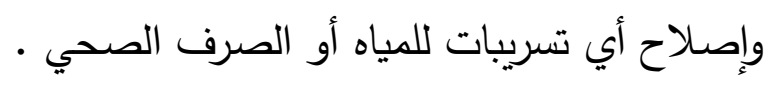

- القيام بتوعية أولياء الأمور بأهمية التعليم المجتمي ومخاطر الأمية وظاهرة التسرب - عمل ندوات تثقيفية لحث الدارسين على أهمية التعليم المجتمي وتوفير مناخ ملأئم لهم. - عمل بروتوكول تعاون بين الإدارة المحلية و منظمات المجتمع المدني لحث المواطنين على التبرع بأراضي لبناء هذه المدارس وتجهيزها. - إصــــدار قانون جديد للإدارة المحلية لتفعيل اللامركزية في كافة المجالات عاما وفي التعليم خاصة لتفعيل دور الإدارة المحلية في تلك المدارس - ضرورة المتابعة المستمرة من قبل القيادات المحلية للعملية التعليمية بمداس التعليم المجتمي • - تقعيل دور الوحدات المحلية عن طريق قيام رؤسـاء المراكز والمدن والأحياء بوضــع خطط لتحسين جودة العملية التعليمية في مدارس التعليم المجتمعي •

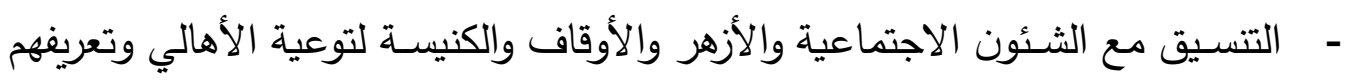

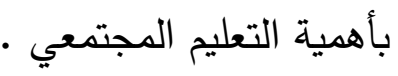
- توفير بند مالي من موازنة المحليات لدعم الإدارة المحلية لهذه المدارس ل نتائجج البحث الميداني:-

توصلت الدراسة الميدانية إلى عدة نتائج وتوصيات من خلال إطارها النظري وواقع تحليل دور الإدارة المحلية في مدارس التعليم المجتمعي كويكن عرض هذه النتائج على النحو التالي:- 


$$
\begin{aligned}
& \text { عدد أكتوبر }
\end{aligned}
$$

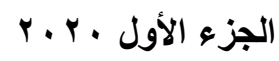

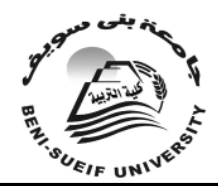

جامعة بني سويف كالفة التريفة مجلة كلية التربية

أولاً:- دور الإدارة المحلية في توفير الاحتياجات الأســــــية لمدارس التعليم المجتمعي و مساهمتها في حل مشكلاتها :- توفير الأدوات والأجهزة اللازمة للأنثـــة المدرســية مثل (ماكينات الخياطة - أجهزة الحاسب الآلي - الأدوات والخامات المستخدمة في النشاط الزراعي والصناعي) - - توفير الأدوات الكهربائية وأدوات المطبخ من بوتاجازات وأجهزة التدبير المنزلي. - توفير المعدات اللازمة للوسائل التعليمية لتحقيق أهداف العملية التعليمية. - - مث رجال الأعمال على تقديم إسهامات مادية لتوفيز الاحتياجات الأساسية لتلك الدارس.

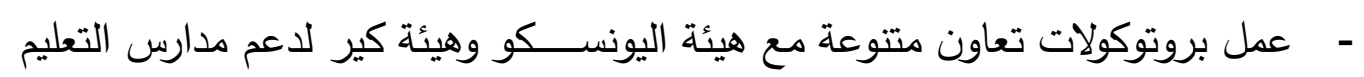

$$
\text { المجتمعي في كافة أنحاء المحافظة. }
$$

ثانياً:- دور الإدارة المحلية في تحسين جودة المباني المدرسية لمدارس التعليم المجتمعي - توفير المتابعة الدورية على المباني المدرسية ومدى ملأمة سلامتها من قبل الإدارات الهنسية. - ت ترميم المباني المدرسية المتهالكة ومتابعة صيانتها. - - صيانة أجهزة الحاسب الآلي الموجودة وتحديثها لكي يستفيد منها الدارسين. - تخصـيص قطع أراضـى مناسـبة لهذه المدارس وحث المواطنين المتيسـرين مادياً في

$$
\text { القرى على التبرع بالأراضي اللازمة. }
$$

ثالثاً:- دور الإدارة المحلية في حل مشكلات الارسـات الاجتماعية والاقتصسادية المتسربات والراسبات من مدارس التعليم المجتمعي

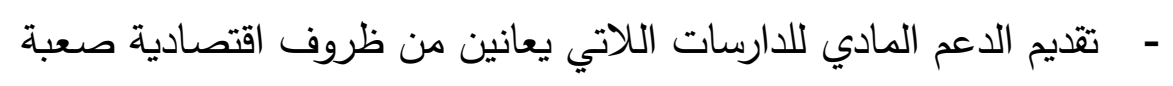
- عمل حفلات وتقديم جوائز للدارسات المتفوقات لتشجيعهن على مواصلة تعليمهن - المساهمة في تقديم وجبات للدارسات خلال اليوم الدراسي

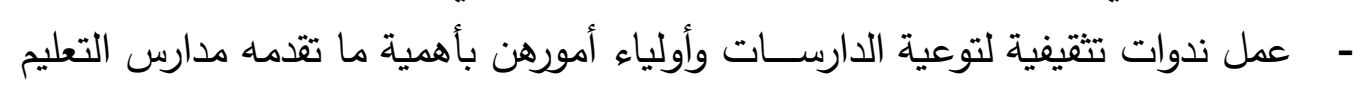
المجتمعي من تعليم حرفة تفيد الدارسات وأسرهم مادياً . - عقد لقاءات شهرية لحل مشكلات الدارسات ودعوة منظمات المجتمع المدني لها. 


$$
\text { الجزء الأول • ع أكتوبر }
$$

رابعاً:- - دور الإدارة المحلية في توفير بيئة تعليمية جاذبة للارسات بمدارس التعليم المجتمعي

- القيام بالتجديدات اللازمة في الفصول لجذب الدارسات للمدرسة

- التسيق مع مديرية التربية والتعليم لتوفير عدد مناسب من الميسرات لهذه المدارس - توفير كافة الأدوات والآلات الموسـيقية التي تسـتخدم في نشـاط الموسـيقى بالمدرســة

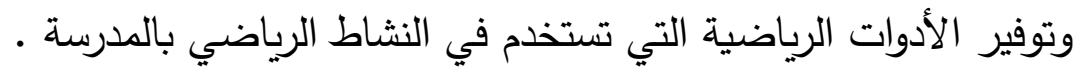

خامساً:- دور الإدارة المحلية في تحسين جودة العملية التعليمية بمدارس التعليم المجتمعي

- تخصـيص نسـبة من صــندوق خدمات المحافظة لاعم العملية التعليمية وتحسـين

$$
\text { جودتها في مدارس التعليم المجتمي. }
$$

- عمل حملة دعاية واسعة لتعريف المجتمع المحلى بماهية مدارس التعليم المجتمعي. - عمل مسابقات بين مدارس التعليم المجتمعي على مستوى جميع أنحاء المراكز وبعضها. - مساعدة هذه المدارس للحصول على الجودة والاعتماد.

- عمل ورش عمل للتلاميذ للتعريف بأهم الحرف الصناعية أو المحاصيل الزراعية التي تشتهر بها المحافظة . 


$$
\begin{aligned}
& \text { عدد أكتوبر }
\end{aligned}
$$

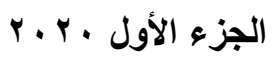

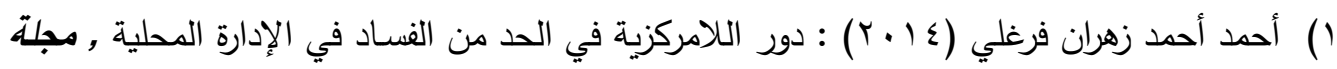

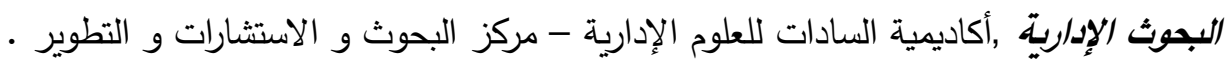

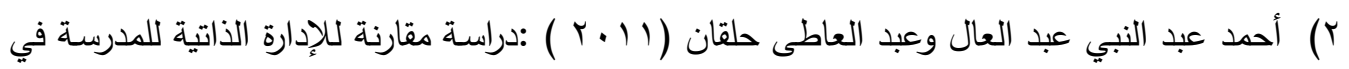

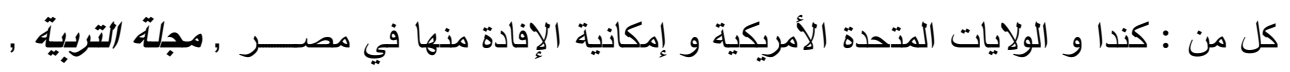

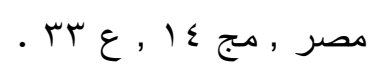

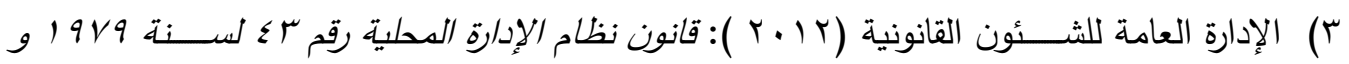

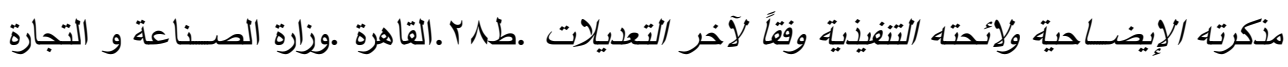

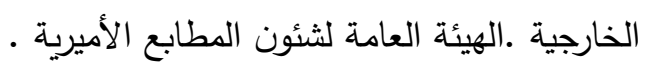

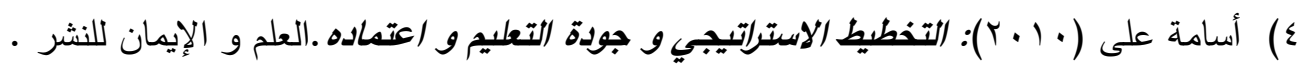

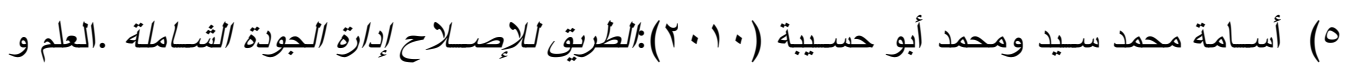
الإيمان للنشر و التوزيع.

7) إيمان أحمد هاني (2011): تطوير مدارس الفصل الواحد للفتيات في ضوء الاحتياجات المجتمعية

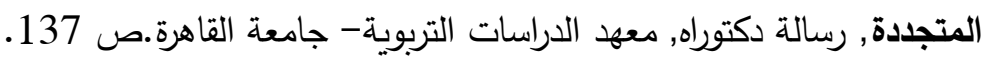

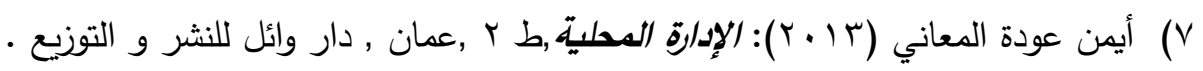

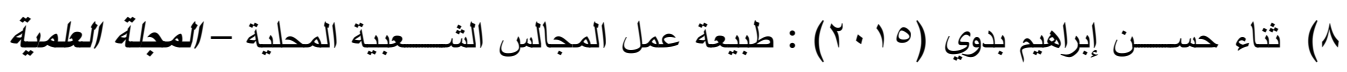

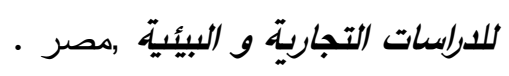

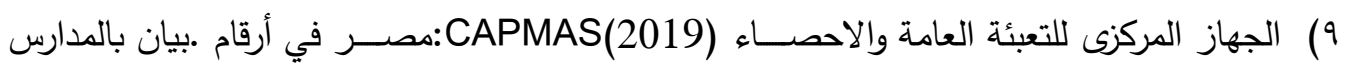

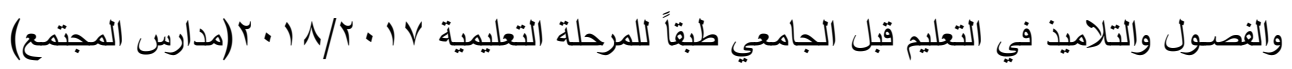
. . ص ال • ()حسـين المبروك عطية (7 ( • r):إدارة الجودة في التعليم.مجلة العلوم و الداراسـات الإنسـانية .كلية

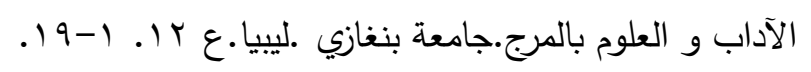

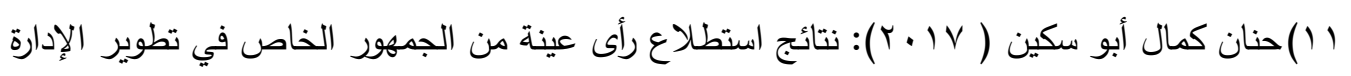

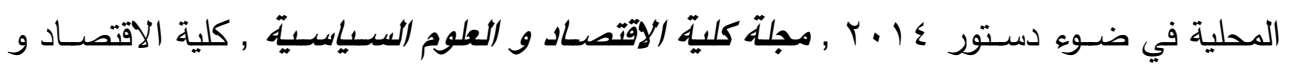

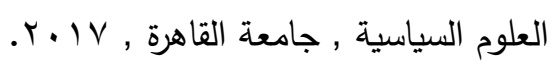

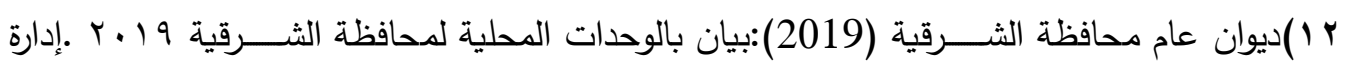
الوحدات المحلية بديوان عام محافظة الشرقية. 
ب ا )رشــيدة الســيد أحمد الطاهر وســماح محمد الدســوقي فرج وعبير حســن مصــــفي حســان

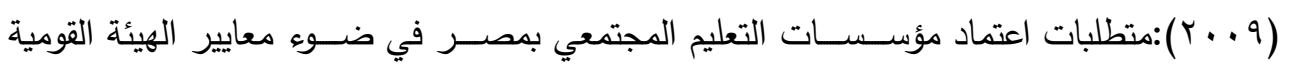

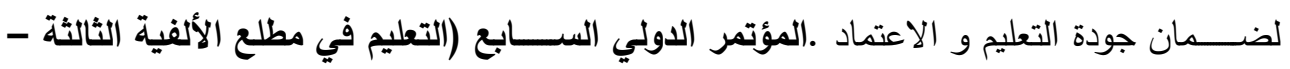

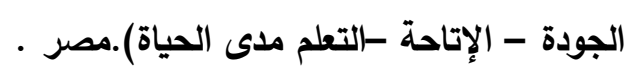

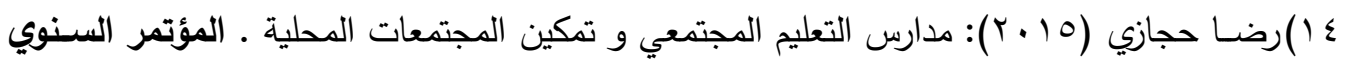

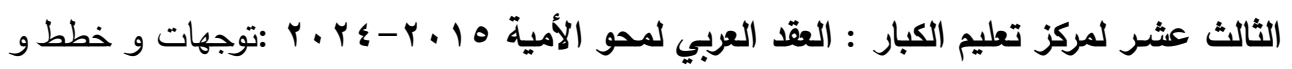
برامج • مركز تعليم الكبار •جامعة عين شمس .مصر .ابريل •

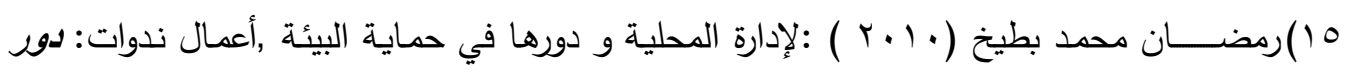
التشربعات و القوانين في حمابية البيئة العربية رالمنظمة العربية للتنمية الإداربية.

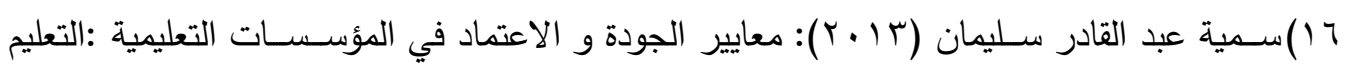
الأساسي و الثانوي في المجتمع الليبي .المؤتمر العلمي العربي السادس و الأول للجمعية المصرية لأصــــل التربية بإلتعاون مع كلية التربية ببنها بعنوان :التعليم ..و أفاق ما بعد ثولات الربيع

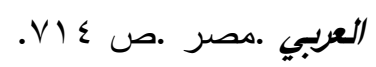

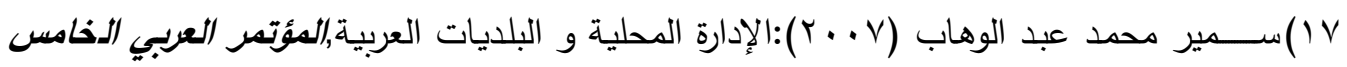
(الإدارة المحلية و البلديات في الوطن العربي).المنظمة العربية للتمية الإدارية ـالأمارات,الثــارقة, • مارس

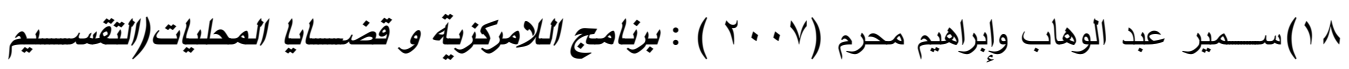
الإد/ري للمدافظات و تأثيره على التنمية المحلية), , كلية الاقتصــاد والعلوم السـياسـية , جامعة القاهرة , مركز دراسات و استثارات الإدارة العامة PARC.

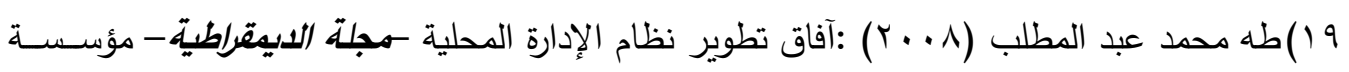

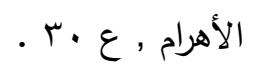

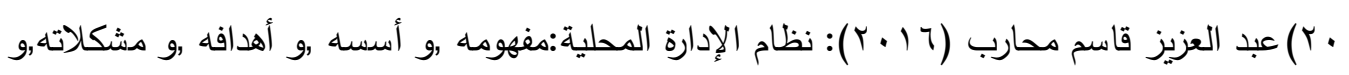

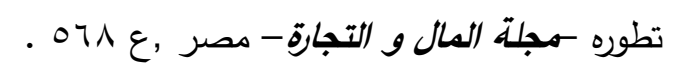

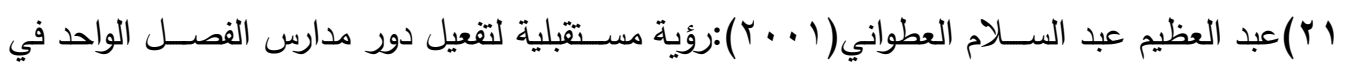
محو أمية الإناث .دراسة مقدمة لمؤتمر تنمية المرأة العربية ـ الإشكاليات و آفاق المستقبل ـ في الفترة من ه- V فبراير.المركز العربي للتعليم و التنمية بالتعاون مع مركز دراسات الجنوب .جامعة جنوب الوادي . 


$$
\begin{aligned}
& \text { عدد أكتوبر } \\
& \text { الجزء الأول • r. r. أكتوير }
\end{aligned}
$$

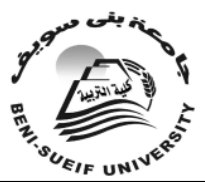

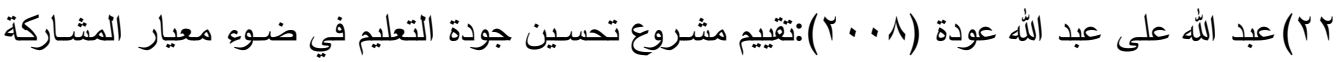
المجتمعية دراسـة مطبقة على مدارس التعليم الأسـاسـي بأسـوان .المؤتمر العلمي الدولي الحادي و

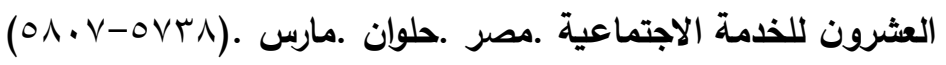

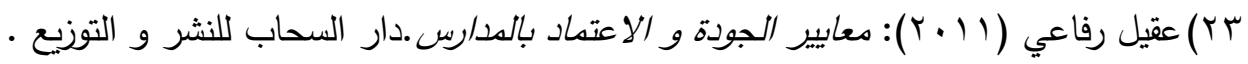

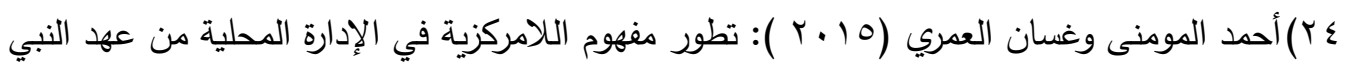
صـلى الله عليه و سـلم إلى أواخر العهد العباسـي :دراسـة مقارنة سمجلة جامعة الملك سعود ,كلية الحقوق و العلوم السياسية .

هب)فاطمة محمد بهجت (2011): الخلفية الاجتماعية لارسـات مدارس الفصـل الواحد ."بحث قرية

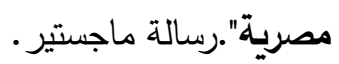

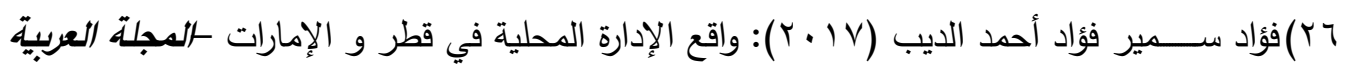
لكلإدارة , المنظمة العربية للتنمية الإدارية . لوادية

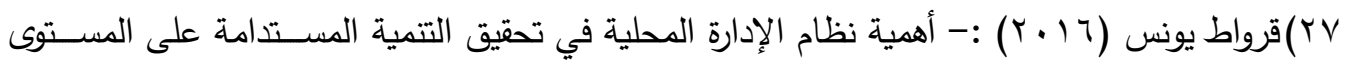
المحلى -الإدارة المحلية في الجزائر و دورها في تحقيق التتمية المستدامة رمجلة الحكمة للدراسـات الاقتصادية ,مؤسسة كنوز الحكمة للنشر و التوزيع ,ع م 1 .

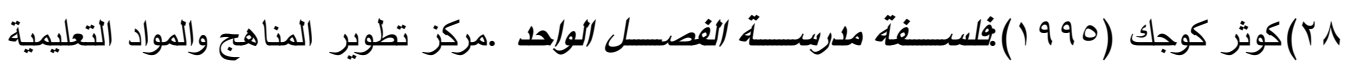
(القاهرة.

qج) المتولي بدير (بدون سـنة):المشـاركة المجتمعية في التعليم (دراسـة حالة) لإحدى المدارس التعاونية،

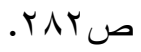

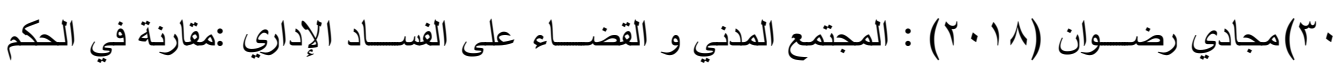
المحلى الرشـيد -ـفاتر السياسـة و القانون -جامعة قاصسي مرباح ورقلة -كلية الحقوق و العلوم السباسبية. اب) المجلس القومي للطفولـة و الأمومـة (2005): المجلس القومي للطفولـة و الأمومـة بالتعاون مع اليونيسيف ـ أطفال خارج نطاق الحماية ـ دراسة تعمقيه عن أطفال الشوارع بالقاهرة الكبرى .القاهرة

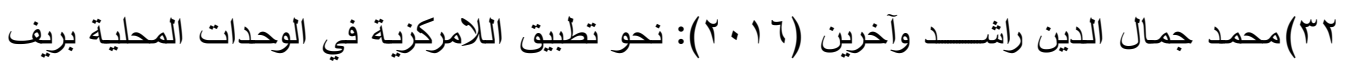
محافظة المنيا التحديات والمعوقات -قسـم المجتمع الريفي والإرشــاد الزراعي -كلية الزراعة جامعة

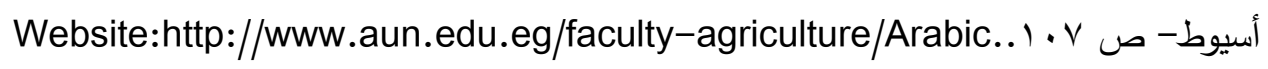




$$
\begin{aligned}
& \text { عدد أكتوبير } \\
& \text { الجزء الأول • r. r. الجوير }
\end{aligned}
$$

سب)محمد رضــــا رجب(غير معروفة):نظام الإدارة المحلية في مصـــر (الواقع وآفاق المســتقبل).بحث

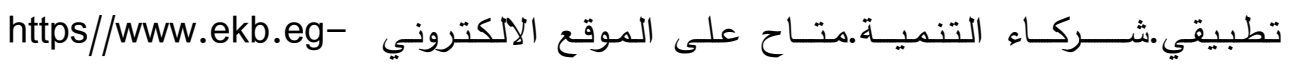
www.mandumah.com ـ ץ)محمد صبري محسوب و آخرون(9 ( • ) ): وطني حياتسي (الدراسات الاجتماعية) , الصف السادس الابتدائي, الفصل الدراسي الأول روزارة التربية و التعليم و التعليم الفني •

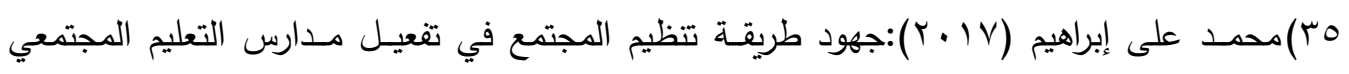
لمواجهة التســرب الدراســـي .مجلة الخدمة الاجتماعية .الجمعية المصـــريـة للأخصــــائيين

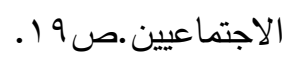
بr)محمد عوض البربري (0 ( ب):مؤسسـات التعليم المجتمعي في الصسين و إمكانية الإفادة منها في

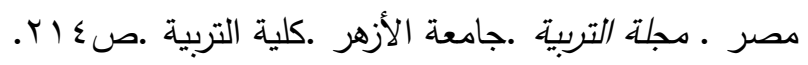

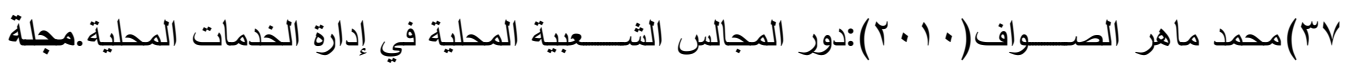

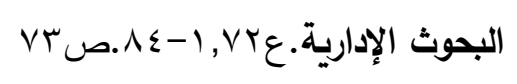

^ץ)محمد محمد عبد الحميد ( . . . ץ): تطوير مدارس الفصل الواحد بجمهورية مصر العربية في ضوء

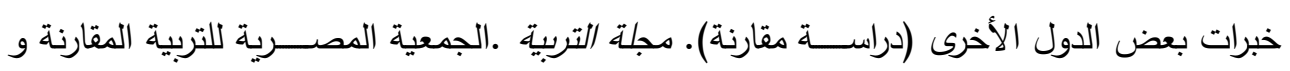

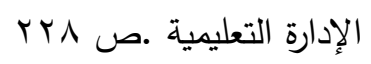

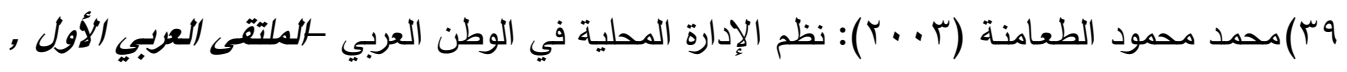

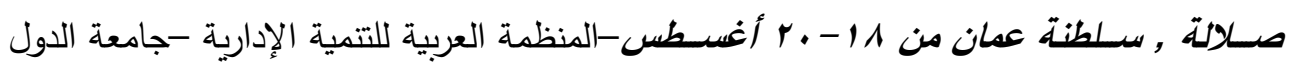
العربية

• ؛ )محمد هيكل (ب99 (1): مشـــروع مدارس الفصـــل الواحد و تجربة مدارس المجتمع .ندوة التعليم الأساسي في مصر واقعه و مستقبله .القاهرة .منظمة الأمم المتحدة للطفولة اليونيسيف رمايو.

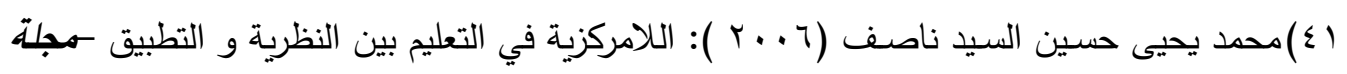

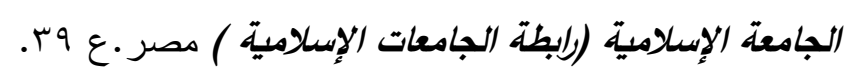
بـ مديرية التربية و التعليم بالثـــرقية (2018):إدارة التخطيطـو المشــروعات بمديرية التربية والتعليم

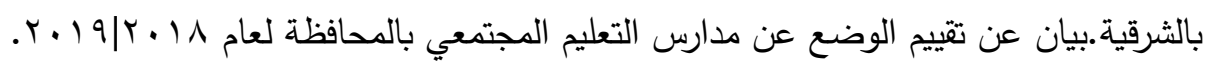

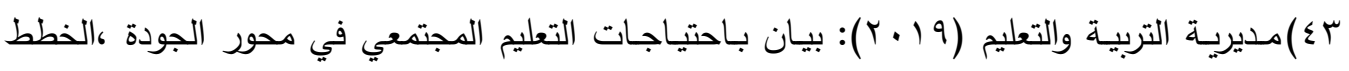
التنفيذية لجميع البرامج التعليمية لمحافظة الثرقية 2018|2019. ـ §)مديرية التربية والتعليم بالثـــرقية (2018):إدارة التخطيطـو المشـــروعات بمديرية التربية والتعليم بالثرقية 2018|2019.بيان عن مدارس التعليم المجتمي بالمحافظة . 


$$
\begin{aligned}
& \text { عدد أكتوبر }
\end{aligned}
$$

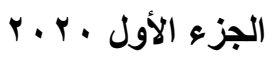

ـ ـ)مراد صــالح زيدان ( . . . ب):فرص التعلم الموازى للتعليم الإلزامي في بعض قرى الريف المصــري

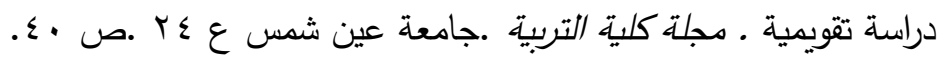

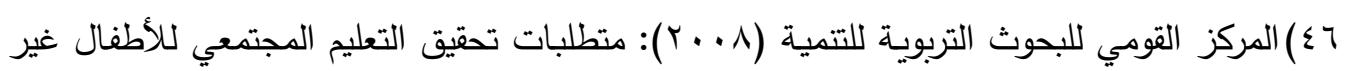
الملتحقين بنظام التعليم .باحث رئيسي عبد الله بيومي. القاهرة .ص 10. V乏)مشيرة إبراهيم صابر عبد اللطيف (2013): مشكلات مدارس الفصل الواحد في مصر و مواجهتها

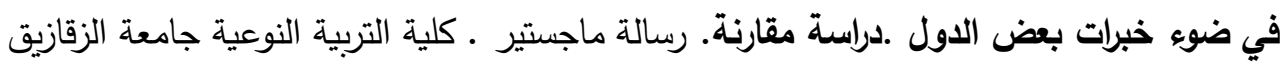

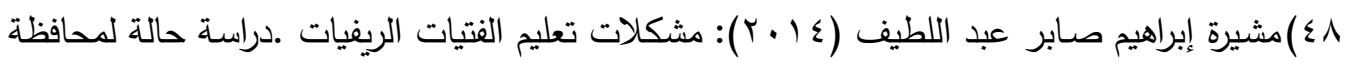

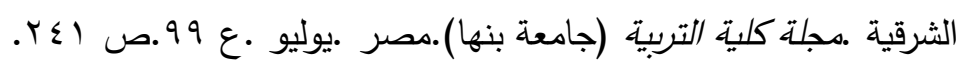

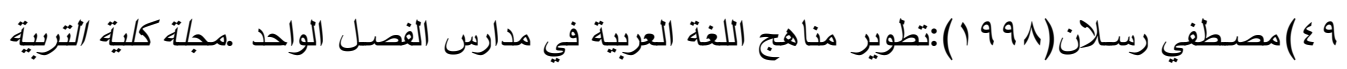

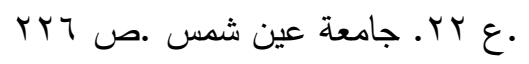
• 0)مصـطفي محمود عفيفي (9 . . ب) :النظام القانوني للإدارة المحلية في مصسر و الدول الأجنبية بين. المركزية و اللامكزية الإدرية - دراســة وصسفية و تحليلية زنظرية و تطبيقية في ظل القانون رقم

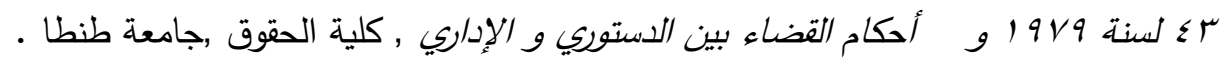
10)ملك زغلول (999 (1): ندوة عن مدرسة الفصل الواحد , الجمعية المصرية للمناهج و طرق التدريس

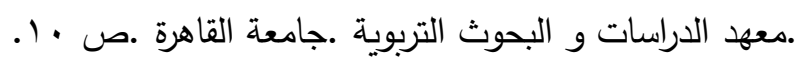
roاديه يوسـف جمال الدين - فاطمة محمد بهجت- دينا حسـن عبد الثـافي (10 • ب): المشــاركة المجتمعية لتطوير مدارس الفصـــل الواحد, مجلة العلوم التربوية ،مصـــر , مج 23, ع3, يوليو, ص ص

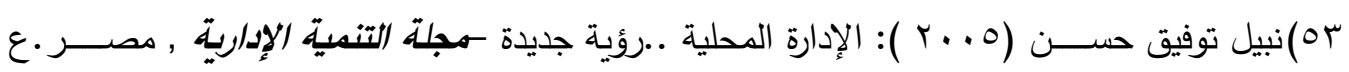
$.1 \cdot 1$

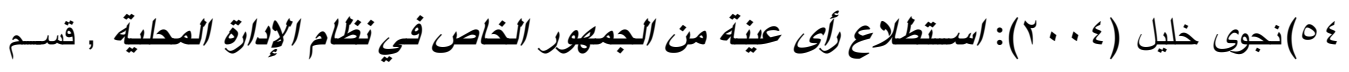
بحوث و قياسات الرأي العام , القاهرة ,المركز القومي للبحوث الاجتماعية و الجنائية . ل 00)نشأت محمد عبد القادر بني حمد (2002): الإدارة المحلية بين النظربية و التطبيق دراسـة مقارنة في قوانبي:مصر • لبنان .الأردن , رسالة ماجستير .جامعة الحكمة , معهد الحكمة العالي لتدريس

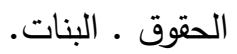




جامعة بني سويفة

10)نهى محمود أحمد محمود (2010):فاعلية برنامج متعدد الوســائط في تنمية التحصـيل والاتجاه

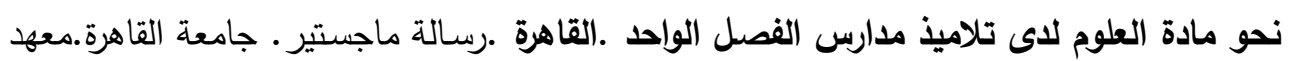

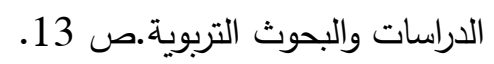

Vالة إبراهيم الجلاد (2008):الهار في مدارس الفصل الواحد و دور المجتمع المحلى في مواجهته "تصور مقترح".رسالة ماجستير غير منشورة .معهد الدراسات و البحوث التربوية . جامعة القاهرة .

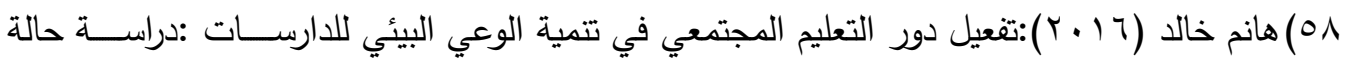

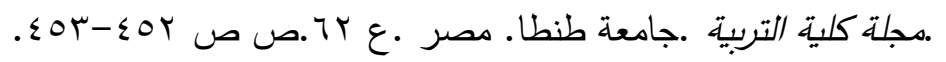

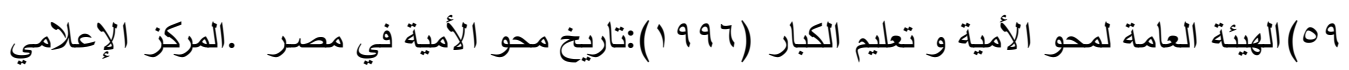
للدراسات و البحوث القومية و الإستراتيجية .القاهرة . لإنية

• ب) الهيئة القومية لضـــمان جودة التعليم والاعتماد (2015):وثيقة معايير ضــــــان جودة و اعتماد مؤسسات التعليم المتمعي .الإصدار الأول.

AL Tuwayjiri Hissah abd allah (2011):understanding schooling quality implementation in england-school of education -NOTTINGHAM UNIVERSITY -MASTER THESIS.

Alo,E.N (2012) fiscal federalism and local government finance in Nigeria Department of political science ,Redeemers University, Nigeria - published on world Journal of Education .

Andrian,D.(2018 ): The instrument development to evaluate local curriculum in Indonesia- international journal of instruction ,no.4 .

Fredenburg.A(1999):"teaching for success, strengthening child -centered classroom" $8^{\text {th }}$,u.s.new Hampshire.

HARASHA S. (2005): decentralized governance and development : the case of panchayats in Karnataka- ph D thesis, university of mysore, My sore .

Kathleen Corak(1993): organization for quality planning for higher education ,vol.21.no.4.p.30.

Peter KEARNS (2005): A Tale of two towns: learning community initiatives in bega valley and thuringowa - research was published in Australian ,JOURNAL OF Adult learning ,volume $45-$ no.3.p372. 


$$
\begin{aligned}
& \text { عدد أكتوبر }
\end{aligned}
$$

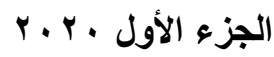

المواقع الإكترونية العربية:

-الخطة الإستراتيجية للتعليم قبل الجامعي 2014 20301/ egyptian knowledge bank -ekb available on ( https://www.ekb.egdaralmandumuh (Almandumah.com.mplbci.ekb.eg )

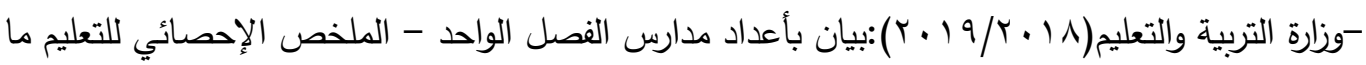

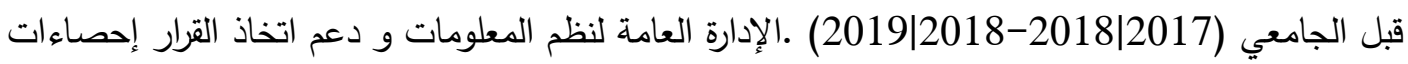

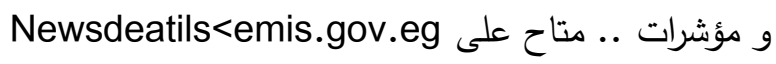
قواميس عربية:- مجمع اللغة العربية : المعجم الوسيط , دار المعارف ,القاهرة ,د,ت.سليمان ص 145 